\title{
Parthenolide Induces Caspase-Independent and AlF-Mediated Cell Death in Human Osteosarcoma and Melanoma Cells
}

\author{
ANTONELLA D'ANNEO, DANIELA CARLISI, MARIANNA LAURICELLA, SONIA EMANUELE, \\ RICCARDO DI FIORE, RENZA VENTO AND GIOVANNI TESORIERE*
}

Dipartimento di Biomedicina Sperimentale e Neuroscienze Cliniche, Sezione di Scienze Biochimiche,

Università degli Studi di Palermo, Palermo, Italy

\begin{abstract}
The mechanism of the cytotoxic effect exerted by parthenolide on tumor cells is not clearly defined today. This article shows that parthenolide stimulates in human osteosarcoma MG63 and melanoma SK-MEL-28 cells a mechanism of cell death, which is not prevented by z-VAD-fmk and other caspase inhibitors. In particular treatment with parthenolide rapidly stimulated (I-2 h) reactive oxygen species (ROS) generation by inducing activation of extracellular signal-regulated kinase I/2 (ERK I/2) and NADPH oxidase. This event caused depletion of thiol groups and glutathione, NF- $\kappa$ B inhibition, c-Jun N-terminal kinase (JNK) activation, cell detachment from the matrix, and cellular shrinkage. The increase of ROS generation together with the mitochondrial accumulation of $\mathrm{Ca}^{2+}$ also favored dissipation of $\Delta \psi \mathrm{m}$, which seemed primarily determined by permeability transition pore opening, since $\Delta \psi \mathrm{m}$ loss was partially prevented by the inhibitor cyclosporin A. Staining with Hoechst 33342 revealed in most cells, at 3-5 h of treatment, chromatin condensation, and fragmentation, while only few cells were propidium iodide (PI)-positive. In addition, at this stage apoptosis inducing factor (AIF) translocated to the nucleus and co-localized with areas of condensed chromatin. Prolonging the treatment $(5-15 \mathrm{~h})$ ATP content declined while PI-positive cells strongly augmented, denouncing the increase of necrotic effects. All these effects were prevented by $\mathrm{N}$-acetylcysteine, while caspase inhibitors were ineffective. We suggest that AIF exerts a crucial role in parthenolide action. In accordance, down-regulation of AIF markedly inhibited parthenolide effect on the production of cells with apoptotic or necrotic signs. Taken together our results demonstrate that parthenolide causes in the two cell lines a caspase-independent cell death, which is mediated by AlF.
\end{abstract}

J. Cell. Physiol. 228: 952-967, 2013. (c) 2012 Wiley Periodicals, Inc.

Parthenolide, the major bioactive sesquiterpene lactone present in Feverfew (Tanacetum parthenium), has recently attracted considerable attention because of its complex pharmacological action involving anti-microbial, antiinflammatory, and anti-cancer effects (Pareek et al., 20II).

Due to anti-inflammatory properties and low toxicity, parthenolide is traditionally used to treat fever, headache, rheumatoid arthritis, and menstrual irregularities (Pareek et al., $20 \mathrm{II}$ ). Its anti-inflammatory effect depends on the ability to inhibit the transcriptional activity of nuclear factor $-\kappa B$ (NF- $\kappa$; Pareek et al., 20II) and the enzymatic activities of 5lipoxygenase and cyclooxygenase (Sumner et al., 1992), which are involved in inflammatory process.

In addition it has been shown that parthenolide may also inhibit proliferation and induce death of several human cancer cells in vitro, such as colorectal cancer (Zhang et al., 2004), pancreatic cancer (Liu et al., 20I0), multiple myeloma (Wang et al., 2006), prostate cancer (Sun et al., 20I0), metastatic melanoma (Czyz et al., 20l0), and cholangiocarcinoma (Kim et al., 2005) cells. In comparison with its well-established antiinflammatory activity, the anti-tumor effect of parthenolide is relatively less documented. Recent findings indicate that the drug triggers apoptosis by inhibiting the activity of the prosurvival transcriptional factor NF- $\mathrm{B}$ or inducing generation of reactive oxygen species (ROS).

NF- $\kappa B$ is a dimeric transcription factor, which has been shown to promote survival of tumor cells and reduce the effectiveness of cancer therapy (Bours et al., 2000; Ravi and Bedi, 2004). This factor is bound to the Inhibitor kappa $B\left(I_{\kappa} B\right)$ protein in an inactive cytosolic complex. Phosphorylation of $I_{\kappa} B$ leads to the release of NF- $\mathrm{B}$, which translocates into the nucleus where promotes the transcription of genes involved in inflammatory response, as well as in regulation of cell proliferation, apoptosis, and angiogenesis. Parthenolide has been shown to inhibit phosphorylation of $I_{\kappa} B$, thus leading to suppression of NF-kB activity (Kwok et al., 200I).

Many lines of evidence indicate that parthenolide induces oxidative stress by increasing production of ROS (Wen et al., 2002; Wang et al., 2006; Zunino et al., 2007). However, the precise mechanism of parthenolide-induced oxidative stress remains unclear, although recently it has been shown that parthenolide can increase in prostate cancer cells ROS generation by activating NADPH oxidase (NOX; Sun et al.,

The authors declare that there is no conflict of interest.

Contract grant sponsor: "Innovative Research Project," 2007, University of Palermo, Italy.

Contract grant sponsor: Ministero dell'Istruzione, dell'Università e della Ricerca" (MIUR).

*Correspondence to: Prof. Giovanni Tesoriere, Dipartimento di Biomedicina Sperimentale e Neuroscienze Cliniche, Sezione di Scienze Biochimiche, Policlinico, via del Vespro 129, 90127 Palermo, Italy. E-mail: giovanni.tesoriere@unipa.it

Manuscript Received: 20 January 2012

Manuscript Accepted: I June 2012

Accepted manuscript online in Wiley Online Library (wileyonlinelibrary.com): II June 2012

DOI: $10.1002 / j c p .24|3|$ 
2010). ROS in its turn can be responsible for alteration of mitochondrial function with the consequent activation of death signaling pathways (Hampton and Orrenius, 1998) or can induce the activation of c-Jun $\mathrm{N}$-terminal kinase (JNK; Shanmugam et al., 2010, 20II).

Finally, it has been ascertained that parthenolide prevents resistance of tumor cells to TRAIL. In breast cancer cells this sensitization involves activation of JNK (Nakshatri et al., 2004), while in hepatocellular carcinoma cells parthenolide increases the surface expression of death receptors TRAIL-RI and R2 (Carlisi et al., 20I I).

However, despite of the efficacy shown by parthenolide in the experiments in vitro, the drug exhibited in vivo only a limited activity due to its poor solubility. Recently it has been generated a dimethylamino analogue of parthenolide (DMAPT), which improves solubility and bioavailability of the drug. This compound has been employed successfully to eradicate acute myelogenous leukemia stem cells (Guzman et al., 2007), and also prostate (Shanmugam et al., 2010), lung and bladder (Shanmugam et al., 20II) cancer cells in vivo. These results authorize the inclusion of parthenolide in new therapeutical strategies against cancer. Consequently a detailed knowledge of the molecular mechanism induced by the sesquiterpene, either when employed alone or in association, becomes necessary.

The aim of this article was to elucidate the mechanism of parthenolide action on two lines of cancer cells, the human osteosarcoma MG63, and the melanoma SK-MEL-28 cells, on which parthenolide exerted its action inducing similar effects.

This article shows that the drug induced in the two cell lines a caspase-independent form of death. After brief treatments $(\mathrm{I}-3 \mathrm{~h})$ the drug caused ROS generation, depletion of protein thiols and glutathione (GSH) and dissipation of the mitochondrial membrane potential $(\Delta \psi \mathrm{m})$. These effects were accompanied by condensation and fragmentation of chromatin. For longer treatments necrotic signs became predominant together with the fall of ATP level. Nuclear translocation of apoptosis inducing factor (AIF) seemed to be the crucial event in the mechanism.

\section{Materials and Methods \\ Chemicals and reagents}

Parthenolide was supplied by Sigma-Aldrich (Milan, Italy). Stock solution of parthenolide was prepared in dimethyl sulfoxide (DMSO) and diluted to final concentration in the culture medium. Final concentration of DMSO employed as vehicle never exceeded $0.04 \%$ and had no discernible effects on MG63 or SK-MEL- 28 cells. All reagents were purchased from Sigma-Aldrich, except for zVAD-fmk and DEVD-cho, which were supplied from Promega (Milan, Italy), and IETD-fmk supplied from Clontech (Palo Alto, CA).

\section{Cell cultures}

MG63 and SK-MEL-28 cells, obtained from "Istituto Scientifico Tumori" (Genoa, Italy), were grown as monolayers in culture medium [DMEM supplemented with $10 \%(\mathrm{v} / \mathrm{v})$ FCS and $2 \mathrm{mM}$ glutamine] at $37^{\circ} \mathrm{C}$ in a humidified atmosphere containing $5 \% \mathrm{CO}_{2}$. Cells were plated on 96 or 6-well plates or on $100-\mathrm{mm}$ culture dishes, then were allowed to adhere overnight in culture medium, before the treatment with chemicals or vehicle only.

\section{Cell viability and cell death assays}

Cell viability was measured by the MTS method using the CellTiter $96{ }^{\mathbb{B}}$ AQueous One Solution Cell Proliferation Assay (Promega) according to the manufacturer's protocol. Dehydrogenase activity in the mitochondria of metabolically active cells converts MTS to formazan, which is soluble in tissue culture medium. The absorbance of the formazan was measured directly at $490 \mathrm{~nm}$ in a 96-well plate using an automatic ELISA plate reader (OPSYS MR, Dynex Technologies, Chantilly, VA).

In order to determine either changes in nuclear morphology or plasma membrane damage, the cells were stained with Hoechst 33342 and propidium iodide (PI), as suggested by Kelly et al. (2003). In particular, cells $\left(6 \times 10^{3} /\right.$ well) were at first stained with Hoechst $33342(2.5 \mu \mathrm{g} / \mathrm{ml}$ medium $)$ for $30 \mathrm{~min}$, washed with PBS, resuspended in culture medium and treated for various times with parthenolide. Then PI $(2.0 \mu \mathrm{g} / \mathrm{ml}$ medium $)$ was added and the incubation was protracted for additional $15 \mathrm{~min}$. At the end cell morphology was visualized by a Leica DC 300F microscope (Leica microsystems, Wetzlar, Germany) using appropriate filters to examine Hoechst 33342 (DAPI filter with excitation wavelength of $372 \mathrm{~nm}$ and emission wavelength of $456 \mathrm{~nm}$ ) and $\mathrm{PI}$ (rhodamine filter with excitation wavelength of $596 \mathrm{~nm}$ and emission wavelength of $620 \mathrm{~nm}$ ). All the images were acquired by Leica Q Fluoro Software.

Apoptotic effects were also studied by flow cytometry analysis using the Annexin V-FITC/PI Apoptosis Detection Kit I (BD Biosciences Pharmingen, San Diego, CA), according to the manufacturer's instructions. Fluorescence of the cells was analyzed by a FACscan (Becton Dickinson, San Diego, CA).

\section{Evaluation of ROS generation and mitochondrial} membrane potential

For fluorimetric analysis MG63 cells $\left(6 \times 10^{3} /\right.$ well) were treated for $30 \mathrm{~min}$ with $50 \mu \mathrm{M}$ 5-(and-6)-carboxy-2', $7^{\prime}$ -

dichlorodihydrofluorescein diacetate $\left(\mathrm{H}_{2}\right.$-DCFDA) fluorescent signal (Wang and Joseph, 1999). After washing parthenolide and other effectors were added and the cells incubated for various times. At the end the medium was removed and substituted with PBS. Fluorimetric assays were performed in a multiwell

fluorescence plate reader (Varian, Palo Alto, CA). The excitation filter was set at $485 \mathrm{~nm}$ and the emission filter at $530 \mathrm{~nm}$. In other cases fluorescence was directly visualized by means of a fluorescence microscope using a FITC filter.

In order to study the effect of parthenolide on mitochondrial membrane potential, MG63 and SK-MEL-28 cells $\left(6 \times 10^{3} /\right.$ well) were treated for various times with parthenolide and other effectors. At the end cells were treated for additional 15 min with JC-I staining solution (Cao et al., 2007) and $\Delta \psi \mathrm{m}$ was evaluated as indicated in the assay protocol supplied by the Cayman Chemical Company (Ann Arbor, MI). Cells were visualized by a fluorescence microscope. Healthy cells with polarized mitochondria were detected using an appropriate filter to examine J-aggregates with red-orange fluorescence (rhodamine filter with excitation wavelength of $596 \mathrm{~nm}$ and emission wavelength of $620 \mathrm{~nm}$ ). Unhealthy cells were detected using a filter to examine JC-I monomers with green fluorescence (FITC filter with excitation wavelength of $485 \mathrm{~nm}$ and emission wavelength of $530 \mathrm{~nm}$ ).

For all determinations fluorescence was visualized by means of a Leica DC 300F microscope (Leica microsystems), using the Leica Q Fluoro Software.

\section{Measurement of intracellular thiols and glutathione}

In order to measure intracellular thiols, cells after the treatment were detached, washed in PBS, and resuspended in $30 \mathrm{mM}$ Tris$\mathrm{HCl}, 3 \mathrm{mM}$ EDTA, $\mathrm{pH}$ 8.2. For determination of protein thiols (Zhang et al., 2004) aliquots were added to $25 \mu \mathrm{l}$ of $1.5 \mathrm{mM}$ DTNB (Ellman's reagent) and $400 \mu \mathrm{l}$ methanol. After centrifugation at $3,000 \mathrm{~g}$ for $5 \mathrm{~min}, 250 \mu \mathrm{l}$ of each supernatant were transferred in a 96-well plate and read at $412 \mathrm{~nm}$. For the analysis of free thiol groups, aliquots were incubated with $25 \mu \mathrm{l} 10 \%$ TCA and centrifuged. Fifty microliters of each supernatant were transferred in a 96-well plate in the presence of $200 \mu \mathrm{l} 0.2 \mathrm{M}$ Tris- $\mathrm{HCl}, \mathrm{pH} 8.9$ and $20 \mu \mathrm{l}$ DTNB. Then the samples were read at $412 \mathrm{~nm}$. The absorbance was determined by an automatic ELISA plate reader. The final content of intracellular thiols was expressed as nanomoles of $\mathrm{SH}$ groups per $10^{5}$ cells. 
The intracellular GSH concentration was measured using a commercial assay, provided by OXIS Research (Portland, OR). After treatment, the cells $\left(2 \times 10^{5} /\right.$ well $)$ were harvested, and centrifuged at $1,000 \mathrm{~g}$ for $8 \mathrm{~min}$. The pellets were washed in PBS and resuspended in $50 \mu \mathrm{l}$ metaphosphoric acid $(5 \mathrm{~g} / 100 \mathrm{ml}$ distilled water). GSH content was measured as described by manufacturer's instructions. Absorbance was read at $400 \mathrm{~nm}$ in a $96-$-well plate reader. The content of intracellular GSH was expressed as nanomoles of $\mathrm{GSH}$ per $10^{5}$ cells.

\section{NF-KB assay}

NF- $\kappa B$ activity was evaluated by an ELISA-based assay (Trans-AM NF- $\kappa B$; Active Motif, Carlsbad, CA) as described by manufacturer's protocol. Briefly, nuclear extracts were prepared as previously reported (Carlisi et al., 20II). Aliquots were placed in 96-well plates pre-coated with the oligonucleotide containing the NF- $\kappa B$ consensus sequence, and NF- $\mathrm{KB}$ activity was detected using a specific antibody for $\mathrm{p} 65$ subunit provided by the kit.

\section{Western blotting analysis}

Cell lysates were prepared as previously reported (Giuliano et al., 1999). Protein samples (30 $\mathrm{g} /$ /ane) were subjected to SDS polyacrylamide gel electrophoresis and then transferred to a nitrocellulose membrane for the detection with specific antibodies. Analyses of phospho-JNK, Cytochrome c oxidase (COX IV) and histone $\mathrm{HI}$ were performed by using specific antibodies produced by Santa Cruz Biotechnology (Santa Cruz, CA) while antibody for AIF was provided by Abcam (San Francisco, CA). All the others antibodies were purchased from Cell Signaling Technology (Beverly, MA). Protein bands were detected by the Enhanced chemiluminescence reagent (Pierce, Rockford, IL) and their intensity was quantified by using Quantity One quantification analysis software (Bio-Rad, Hercules, CA). The correct protein loading was ascertained by means of both red Ponceau staining and immunoblotting for $\beta$-actin. All the blots shown are representative of at least three separate experiments.

\section{Measurement of adenosine triphosphate}

Intracellular ATP was measured by using the ATP colorimetric/ fluorimetric assay kit supplied by Abcam. Cells $\left(2 \times 10^{5} /\right.$ well) were lysed in $100 \mu$ l of ATP assay buffer; then $10 \mu \mathrm{l}$ of $2 \mathrm{~N}$ perchloric acid were added in order to remove proteins, followed by $20 \mu \mathrm{l}$ of buffer containing $5 \mathrm{M} \mathrm{KOH}$ and $3 \mathrm{M} \mathrm{KHCO}_{3}$. After centrifugation for $2 \mathrm{~min}$ at $15,000 \mathrm{~g}, 20 \mu \mathrm{l}$ of the supernatant were transferred to 96-well plate and developed according to the manufacturer's instructions. The absorbance was read at $570 \mathrm{~nm}$ using an automatic ELISA plate reader.

\section{Measurement of calcium level}

Cytosolic calcium level was measured using Fluo-3AM (SigmaAldrich; Zhang et al., 2004). Cells $\left(2 \times 10^{5} /\right.$ well) were collected, washed twice with cold calcium-free PBS and then incubated with $5 \mu$ M Fluo-3AM for $60 \mathrm{~min}$ at $37^{\circ} \mathrm{C}$ in darkness. Then the cells were analyzed by flow cytometry on a Beckman Coulter Epics XL flow cytometer (Brea, CA) using the Expo32 software.

\section{Detection of cytochrome $c$ and AIF}

Cells $\left(7 \times 10^{6} / 100-\mathrm{mm}\right.$ culture dish) were washed twice in PBS, resuspended in lysis buffer $(20 \mathrm{mMHepes}, \mathrm{pH} 7.5,250 \mathrm{mM}$ sucrose, I. $5 \mathrm{mM} \mathrm{MgCl}_{2}, 10 \mathrm{mM} \mathrm{KCl}$, I mMEGTA, I mMEDTA, I mMPMSF, and protease inhibitors) and homogenized with a Teflon homogenizer. In order to perform subcellular fractionation homogenates were centrifuged at $1,000 \mathrm{~g}$ for $10 \mathrm{~min}$ at $4^{\circ} \mathrm{C}$. The pellet was used to prepare the nuclear fraction (Carlisi et al., 2008). The supernatant was centrifuged again at $10,000 \mathrm{~g}$ for $30 \mathrm{~min}$; the resulting pellet represented the mitochondrial fraction, while the

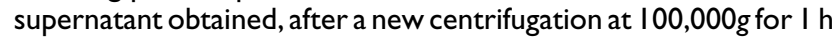
at $4^{\circ} \mathrm{C}$, represented the cytosolic fraction. The pellets for nuclear and mitochondrial fractions were lysed and sonicated. Aliquots of mitochondrial and cytosolic fractions were used to measure the level of cytochrome $c$ by an ELISA kit (Abnova, Taipei, Taiwan) according to the manufacturer's instructions. The absorbance was read at $450 \mathrm{~nm}$ using an automatic ELISA plate reader. The content of AIF was ascertained by western blotting analysis using $30 \mu \mathrm{g}$ of proteins of the mitochondrial and nuclear fractions (Arnoult et al., 2002). COX IV and histone $\mathrm{HI}$ were used as mitochondrial and nuclear markers, respectively.

In order to study the intracellular localization of AIF, cells $\left(6 \times 10^{3} /\right.$ well $)$ were at first treated with Hoechst $33342(2.5 \mu \mathrm{g} / \mathrm{ml}$ medium) and then incubated with parthenolide for the established times. At the end the cells were fixed for $5 \mathrm{~min}$ with $3 \%$ paraformaldehyde, permeabilized for 5 min with $0.1 \%$ Triton X-100 and incubated with a blocking solution (PBS containing I\% BSA) for $\mathrm{I} h$ at room temperature and then with rabbit monoclonal antihuman AIF antibody (Abcam) (I:100 in PBS) overnight at $4{ }^{\circ} \mathrm{C}$, followed by $2 \mathrm{~h}$ with $\mathrm{I}: \mathrm{I} 00$ dilution of FITC-conjugated secondary antibody (Santa Cruz Biotechnology). Finally, cells were visualized with a Leica DC300F microscope with DAPI filter (excitation wavelength of $372 \mathrm{~nm}$ and emission wavelength of $456 \mathrm{~nm}$ ) and FITC filter (excitation wavelength of $485 \mathrm{~nm}$ and emission wavelength of $530 \mathrm{~nm}$ ) for Hoechst and AIF, respectively.

\section{Down-regulation of AIF by short interfering RNA (siRNA)}

Cells were plated in a 6 -well plate $\left(7.5 \times 10^{4}\right.$ cells/well) and cultured in DMEM supplemented with $10 \%$ FBS for $24 \mathrm{~h}$ to reach approximately $60-80 \%$ confluence before transfection. For silencing experiments, a specific siRNA directed against human AIF (Santa Cruz Biotechnology) as a pool of double-stranded RNA oligonucleotides was used. Briefly, cells were transfected for $6 \mathrm{~h}$ with $80 \mathrm{nM}$ AIF siRNA in the presence of $5 \mu \mathrm{l}$ Metafectene Pro (Biontex, Munich, Germany) in a final volume of I $\mathrm{ml}$ serum-free DMEM. At the end, the reaction was stopped replacing the culture medium with DMEM + 10\% FCS. Cells were examined for AIF down-regulation and other properties $18 \mathrm{~h}$ after transfection. A scramble siRNA was used as negative control.

\section{Statistical analysis}

Results are presented as means \pm standard error. Data were analyzed using the Student's $t$-test.

\section{Results \\ Parthenolide decreases cell viability and induces cell detachment}

Some preliminary experiments were performed to ascertain the dose and the time dependence of the effect exerted by parthenolide on the viability of MG63 and SK-MEL-28 cells. To this end cells were treated for different times $(2-15 \mathrm{~h})$ with various doses (10-100 $\mu \mathrm{M})$ of parthenolide and the viability was assessed by MTS assay. The dose-dependence, studied at $15 \mathrm{~h}$ of treatment (Fig. IA), showed that the cytotoxic effect appeared at $10 \mu \mathrm{M}$ parthenolide, when cell viability decreased by $15 \%$ and $25 \%$ for MG63 and SK-MEL-28 cells, respectively. Then viability diminished with the dose of parthenolide so that at $25 \mu \mathrm{M}$ viable cells lowered in the two lines to $25 \%$ and $15 \%$ of the control values. Afterwards viability declined more slowly, reaching at $100 \mu \mathrm{M}$ parthenolide values of about $20 \%$ and $10 \%$ of the controls. Therefore, the dose of $25 \mu \mathrm{M}$ was chosen for all the experiments performed to investigate about the various effects induced by parthenolide. The time course study (Fig. IB) showed that treatment with $25 \mu \mathrm{M}$ parthenolide rapidly reduced cell viability and at $5 \mathrm{~h}$ of treatment the number of viable cells fell to about $32 \%$ for MG63 cells and 19\% for SKMEL-28 cells with respect to the related controls. Then viability declined more slowly with the time, reaching at $15 \mathrm{~h}$ values of about $25 \%$ and $15 \%$ of the controls. 
A

MG63

$\square \mathrm{PN}$

SK-MEL-28

$\square \mathrm{PN}+2 \mathrm{mM} \mathrm{NAC}$

$\square \mathrm{PN}+100 \mu \mathrm{M} \mathrm{Z}-\mathrm{VAD}$

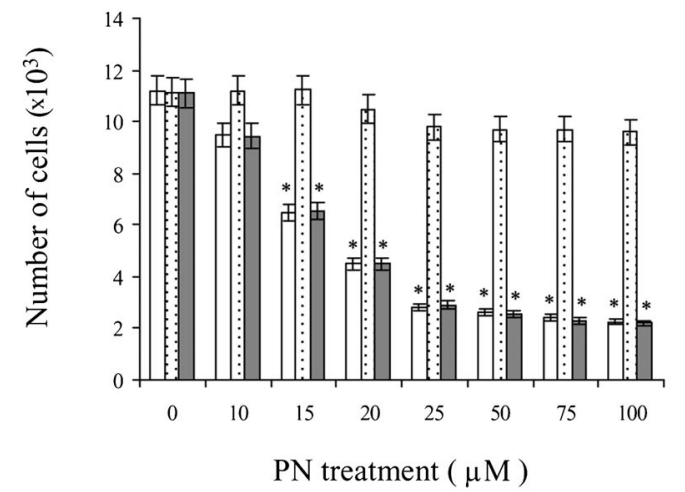

B

MG63

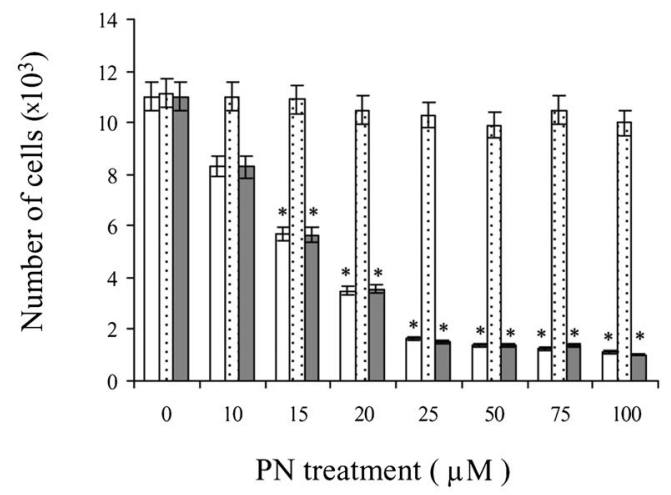

SK-MEL-28

$\square \mathrm{Ctr}$

$\square 25 \mu \mathrm{M}$ PN

드 $25 \mu \mathrm{M} P \mathrm{PN}+2 \mathrm{mM} N A C$

$\square 25 \mu \mathrm{M} \mathrm{PN}+100 \mu \mathrm{M} z-V A D$

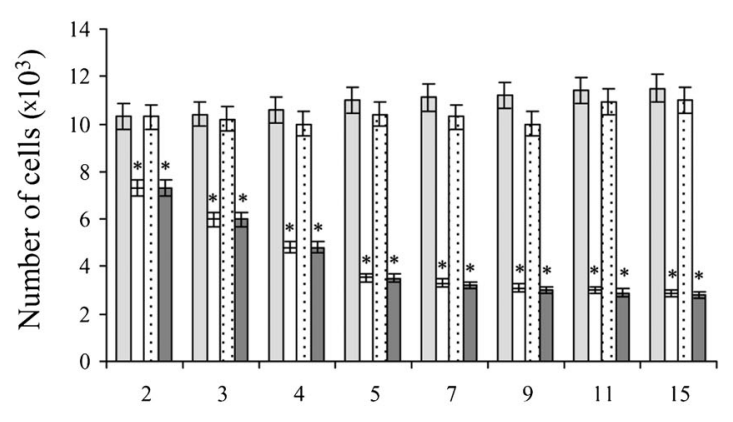

PN treatment (h)

C

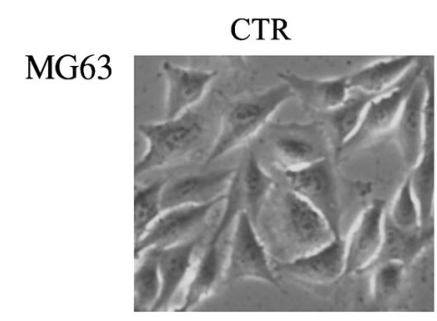

SK-MEL-28

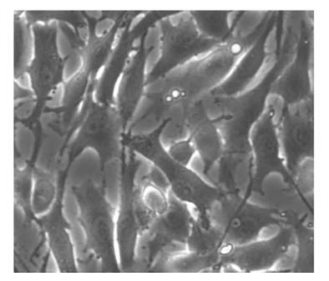

$25 \mu \mathrm{M}$ PN (2h)
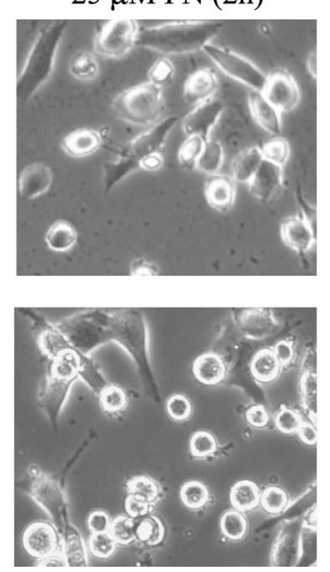

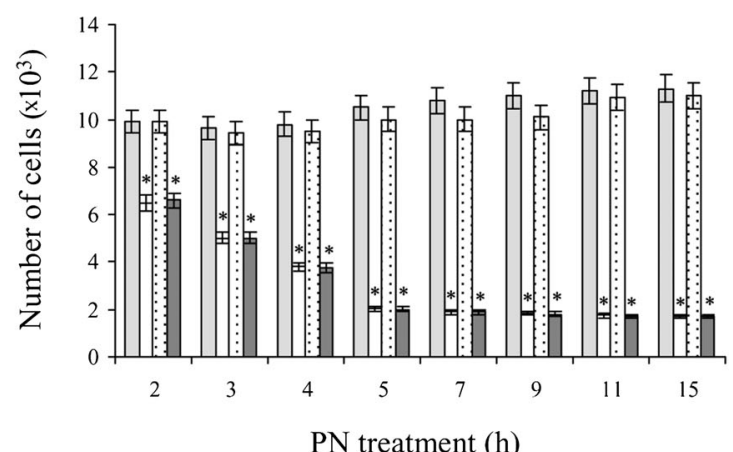

PN treatment (h)

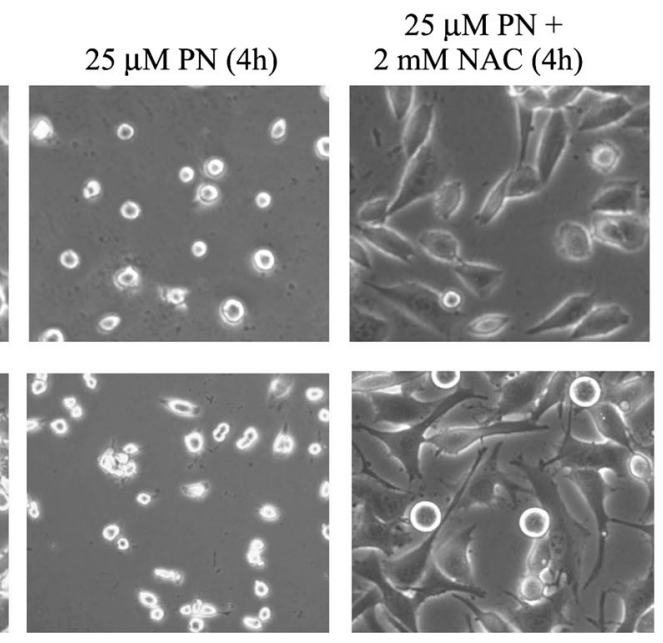

Fig. I. The cytotoxic effect exerted by parthenolide on MG63 and SK-MEL-28 cells. A,B: Effects of parthenolide on cell viability. Cells were treated with different doses of parthenolide for various times without or with $100 \mu M$ z-VAD-fmk or 2 mM NAC. Cell viability was assessed by the MTS method according to the manufacturer's instructions. A: Dose-dependence of the cytotoxic effect at I $5 \mathrm{~h}$ of treatment. B: Time course of the cytotoxic effect exerted by $25 \mu \mathrm{M}$ parthenolide. C: Morphologic changes of MG63 and SK-MEL-28 cells observed under light microscopy at $200 \times$ magnification. Cells $\left(6 \times 10^{3} /\right.$ well) were treated for 2 or 4 h with $25 \mu M$ parthenolide without or with 2 mM NAC. In (A) and (B) values are the means of three independent experiments $\pm S E$. ${ }^{*} P<0.0 \mathrm{I}$ versus untreated control. In (C) the results are representative of three independent experiments. 
The addition of $100 \mu M z-V A D-f m k$ was ineffective in both cell lines, whatever was the time and the dose employed, while parthenolide effect was totally abolished by the addition of 2 mM N-acetylcysteine (NAC).

Other preliminary experiments were performed to evaluate morphological changes induced by parthenolide in MG63 and SK-MEL-28 cells. Control cells displayed under light microscopy (Fig. IC) an adhesive and widened morphology. Treatment for $2 \mathrm{~h}$ with $25 \mu \mathrm{M}$ parthenolide induced detachment of a large percentage of cells (70-75\%). Moreover cells deprived of anchorage assumed soon a rounded shape. Prolonging the time of treatment $(4 \mathrm{~h})$ most of cells showed a remarkable reduction in cell volume. It is interesting to note that when $2 \mathrm{mM}$ NAC was added together with parthenolide, both MG63 and SK-MEL-28 cells maintained the adhesive morphology. Therefore, NAC prevented cell detachment and the successive shrinkage.

\section{Fluorescence microscopy and flow cytometric analysis of parthenolide effects}

In order to ascertain the mode of cell death induced by parthenolide in MG63 and SK-MEL-28 cells we analyzed by fluorescence microscopy the effects of the drug in cells stained with Hoechst 33342 and PI.

Hoechst 33342 penetrates the plasma membrane and emits blue fluorescence when bound to DNA. Therefore, cells showing chromatin condensation (CC) in their nuclei have stronger blue fluorescence when compared to control cells (Kelly et al., 2003). Instead PI is a cell-impermeable nuclear dye which stains the nuclei of the cells (red fluorescence) that have lost plasma membrane integrity and are considered to be necrotic.

Figure $2 \mathrm{~A}$ shows merged images at $100 \times$ magnification related to the effects induced by parthenolide treatment at 3 and $\mathrm{I} 2 \mathrm{~h}$ in both cell lines. Higher magnification $(400 \times)$ of MG63 cells permitted to observe (Fig. 2B) at $3 \mathrm{~h}$ of treatment the presence of PI-negative cells which exhibited positivity to Hoechst, nuclear shrinkage and CC. In addition many of these cells also exhibited chromatin fragmentation. At $12 \mathrm{~h}$ of treatment a high percentage of cells showed pink fluorescence since the loss of membrane integrity allowed PI to enter the cells, which therefore were stained with both the dyes. Identical observations were made for SK-MEL-28 cells (not shown).

Time course experiments performed for both cell lines (Fig. 2C) showed that in the first phase of treatment $(0-5 \mathrm{~h})$ the number of cells, which exhibited brilliant blue fluorescence and chromatin condensation (CC cells), rapidly rose, reaching at $5 \mathrm{~h}$ a percentage of about $85 \%$. Instead in this phase only a limited number of cells appeared positive to $\mathrm{PI}$ ( $15-25 \%$ at $5 \mathrm{~h}$ ). Prolonging the time of treatment (5-15 h) the number of PIpositive cells showing pink fluorescence (PF cells) progressively increased so that at $15 \mathrm{~h}$ PF cells reached $60 \%$ and $72 \%$ of the total cells counted in the field for MG63 and SK-MEL-28 cells, respectively.

The modifications induced by parthenolide treatment in both cell lines were not prevented by the addition of $100 \mu \mathrm{Mz}$-VADfmk, a general inhibitor of caspases (Fig. 2A), or other caspase inhibitors, such as DEVD-cho $(100 \mu \mathrm{M})$ or IETD-fmk (I0 $\mu \mathrm{M})$ (not shown), whatever was the time of treatment. Instead our results show that $2 \mathrm{mMNAC}$ abolished parthenolide effects during $15 \mathrm{~h}$ of treatment (not shown).

In addition we evaluated, using Annexin V-FITC/PI staining method, whether the cytotoxic action of parthenolide was associated with the exposure of phosphatidylserine on the cell membrane. For these experiments cells were treated for various times $(5,8,12$, and $15 \mathrm{~h}$ ) with $25 \mu \mathrm{M}$ parthenolide. Then, $5 \times 10^{3}$ cells per sample were analyzed by FACscan flow cytometer. As shown in Figure 3, treatment for $5 \mathrm{~h}$ did not increase in both cell lines the percentage of cells with early apoptotic signs (C4 area). Prolonging the time of treatment the population of cells that underwent necrosis (PI-positive cells, $\mathrm{Cl}$ area) was progressively increased, reaching at $\mathrm{I} 5 \mathrm{~h}$ levels of about $53 \%$ and $60 \%$ for MG63 and SK-MEL-28 cells, respectively (Fig. 3).

\section{Parthenolide stimulates ROS generation}

To find the cause of the rapid inhibitory action exerted by parthenolide on cell viability we examined the effect of the drug on the production of ROS in the two cell lines. As shown in Figure 4A, fluorimetric assays demonstrated that parthenolide rapidly induced production of ROS. Treatment with $25 \mu \mathrm{M}$ parthenolide stimulated in both cell lines ROS generation already at $30 \mathrm{~min}$ of treatment, while the maximum effect was observed at $2 \mathrm{~h}$.

In agreement with this finding also fluorescence microscopy showed that parthenolide rapidly induced ROS generation in a high percentage of treated cells. In fact, as shown in Figure 4B, most of MG63 cells, pre-treated with the fluorochrome $\mathrm{H}_{2}$-DCFDA, exhibited green fluorescence already at $\mathrm{I} h$ of treatment with parthenolide. Identical results were obtained for SK-MEL-28 cells (not shown).

Parthenolide effect on ROS generation was inhibited by a treatment with different antioxidants, NAC, apocynin, diphenyleneiodonium (DPI), and rotenone (Fig. 4B,C). NAC is an effective scavenger for free radicals. Apocynin and DPI prevent the production of superoxide anion through the inhibition of NOX (Wu et al., 2008), whereas rotenone is known to reduce the production of ROS by inhibiting the mitochondrial electron transport system (Batandier et al., 2006). Such an effect of parthenolide was also diminished by the inhibitor of extracellular signal-regulated kinase I/2 (ERK I/2) U0I 26 (Dewas et al., 2000; Satoh et al., 2000). ERK I/2 is a kinase which has been shown to enhance NOX-I transcription (Moon et al., 20l0). Moreover our article demonstrates, according to previous reports of other authors (Kurdi and Booz, 2007; Kurdi et al., 2007), that brief treatments ( $\mathrm{I}-4 \mathrm{~h}$ ) with parthenolide stimulated in both cell lines phosphorylation and activation of ERK I/2 (Fig. 4D). Therefore, it seems likely that also UOI 26 can inhibit parthenolide effect on ROS generation through a reduction of NOX activity.

The results of our experiments for both cell lines show (Fig. 4B,C) that NAC was the most effective inhibitor, since it annulled parthenolide effect on ROS generation. At I h of treatment the highest effect, apart from NAC, was exerted by apocynin and DPI, which reduced the cells showing green fluorescence by $60 \%$, followed by $\cup 0 \mathrm{I} 26(-45 \%)$, and rotenone $(-40 \%)$. However this last compound was shown to be more effective than apocynin, DPI, and U0I 26 when the cells were treated with parthenolide for longer periods of time $(4 \mathrm{~h}$, Fig. 4C). At last ROS generation was not prevented by caspase inhibitors (not shown).

Finally, we investigated whether ROS generation can be correlated with the activation of autophagic mechanism. To test this possibility cells were treated with parthenolide and then incubated with $50 \mu \mathrm{M}$ monodansylcadaverine (MDC) in PBS at $37^{\circ} \mathrm{C}$ for $15 \mathrm{~min}$. At the end the medium was replaced with PBS and the cells were analyzed by fluorescence microscopy. The analysis suggested that parthenolide did not induce the production of autophagic vacuoles in both cell lines (not shown). Therefore, it seems that autophagy is not involved in parthenolide-induced cell death.

\section{Parthenolide causes depletion of intracellular thiols}

The finding that parthenolide rapidly caused ROS generation suggested to us, in accordance with Zhang et al. (2004), that the 
A
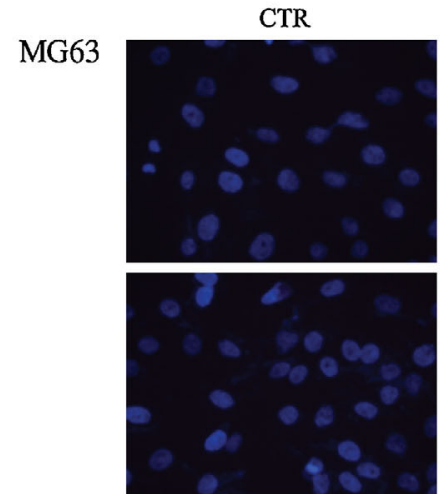

SK-MEL-28
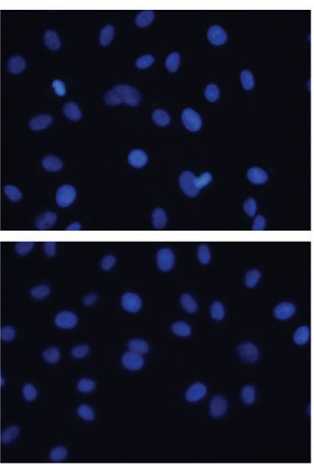

B

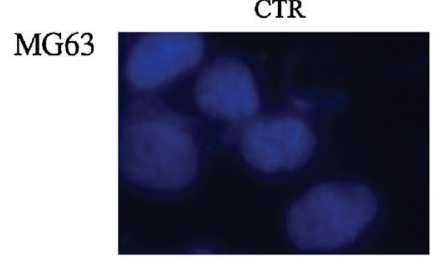

MG63
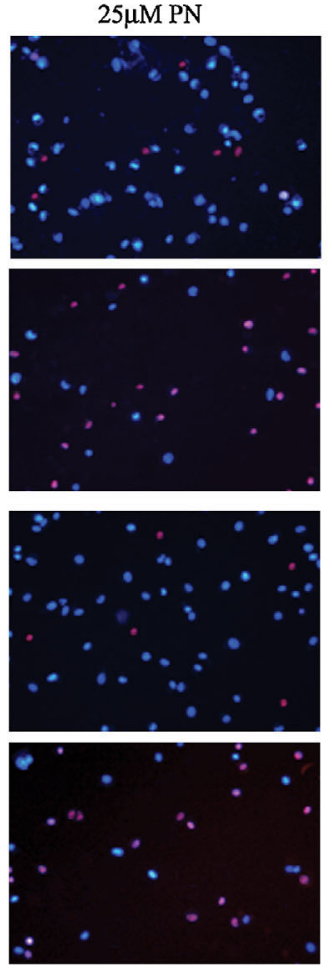

(a) $25 \mu \mathrm{M}$ PN (3h)

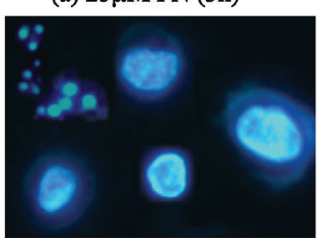

- CC cells
$25 \mu \mathrm{M} P N+100 \mu \mathrm{M} z-V A D$

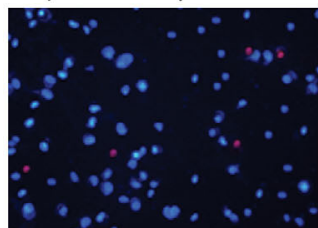

$3 h$
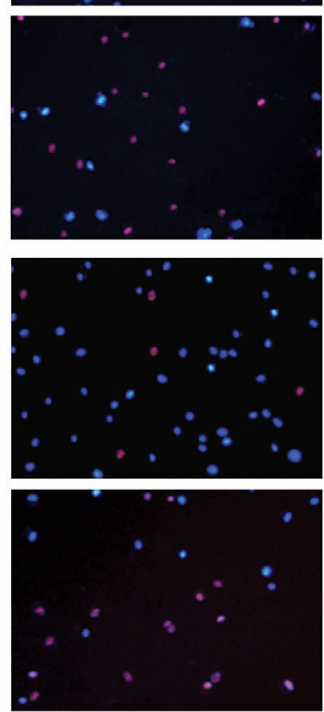

(b) $25 \mu \mathrm{M} P N(12 \mathrm{~h})$

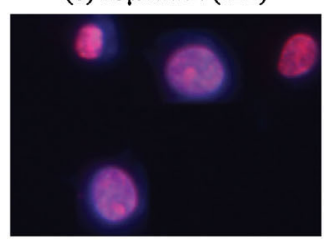

SK-MEL-28

C

$$
\text { - } \mathrm{PF} \text { cells }
$$
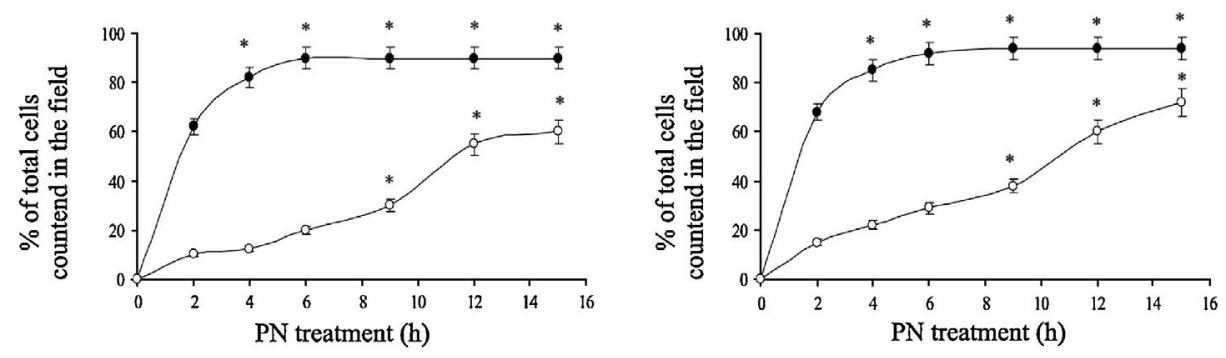

Fig. 2. Fluorescence microscopic images showing the effects of parthenolide treatment after Hoechst 33342 and PI staining. MG63 and SK-MEL28 cells $\left(6 \times 10^{3} /\right.$ well $)$ were stained with Hoechst $33342(2.5 \mu \mathrm{g} / \mathrm{ml}$ medium; blue fluorescence) and then treated with $25 \mu \mathrm{M}$ parthenolide for various times. At the end the cells were incubated for additional 15 min with PI ( $2.0 \mu \mathrm{g} / \mathrm{ml}$ medium; red fluorescence). Cell morphology was visualized with a Leica DC 300F microscope with fluorescent filters for DAPI and rhodamine. A: Merged images at I00 $\times$ magnification of both MG63 and SK-MEL-28 cells treated with parthenolide for 3 and $I 2 \mathrm{~h}$ without or with $100 \mu \mathrm{Mz}-\mathrm{VAD}-\mathrm{fmk}$. B: Merged images at $400 \times$ magnification of MG63 cells. a: Cells treated with parthenolide for $3 \mathrm{~h}$. The image shows cells with condensation and fragmentation of chromatin. b: Cells treated with parthenolide for $\mathrm{I} 2 \mathrm{~h}$ showing PF and signs of both apoptosis and necrosis. C: Time course study showing morphological modifications induced by parthenolide in MG63 and SK-MEL-28 cells. CC cells, cells containing condensed chromatin, either negative or positive to PI; PF cells, PI-positive cells with both PF and condensed chromatin. Cells were counted in three different microscopic fields in each well (three wells per treatment) and expressed as percentage of the total number of cells counted in the field. In (A) and (B) the results are representative of three independent experiments. In $(C)$ values are the means of three independent experiments $\pm S E$. ${ }^{*}<<0.01$ versus untreated control. 


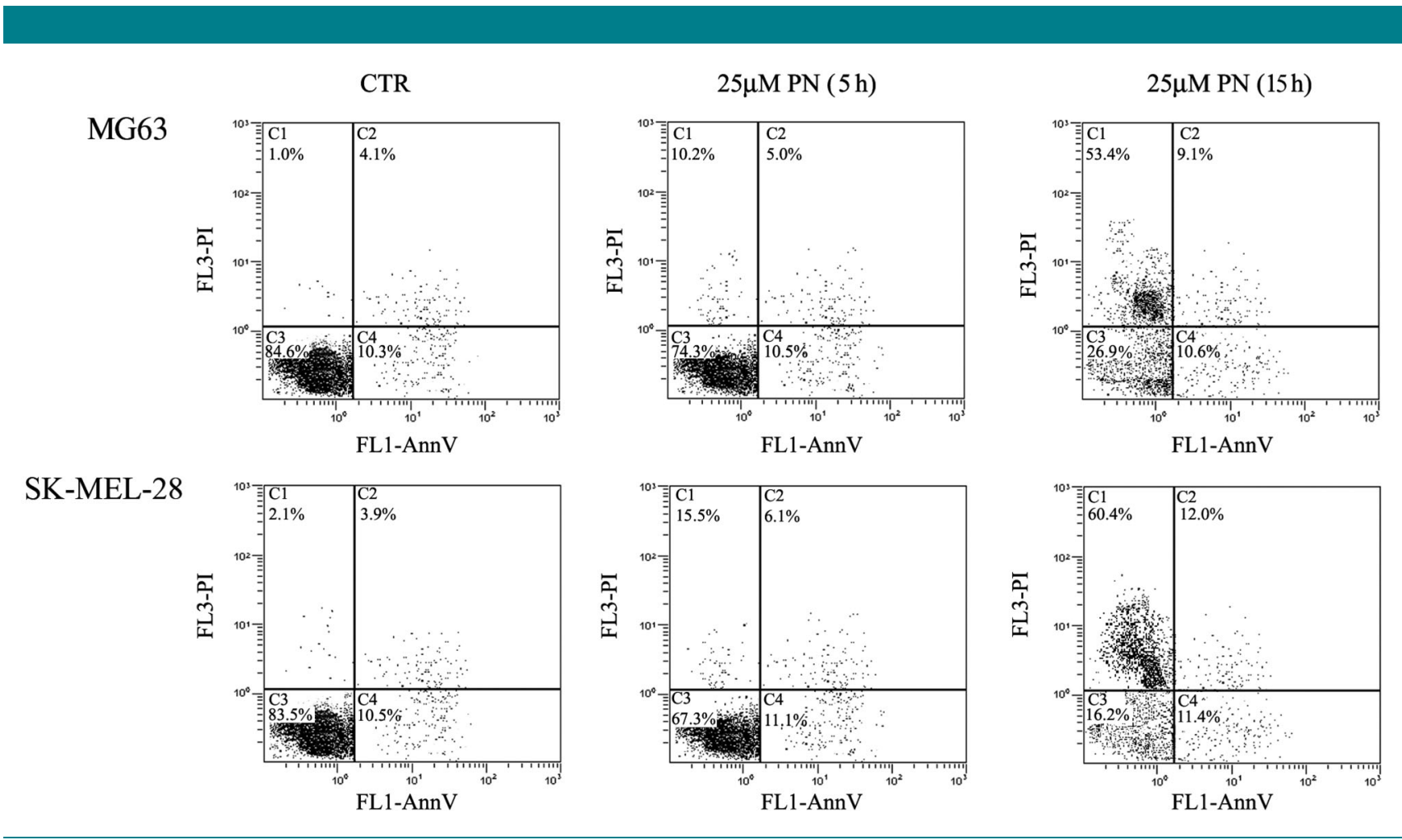

Fig. 3. Flow cytometric analysis of parthenolide effect on MG63 and SK-MEL-28 cells. Cells were treated with $25 \mu$ M parthenolide for 5 and $I 5$ h $\mathrm{I} \times 10^{5}$ cells of each sample were double stained with Annexin V/PI, as reported in methods, and $5 \times 10^{3}$ cells per sample were analyzed by flow cytometry. The $\mathrm{Cl}$ area represents cell necrosis, the $\mathrm{C} 2$ area represents late apoptosis, the $\mathrm{C} 3$ area represents the living cells and the $\mathrm{C} 4$ area represents early apoptotic cells. The results are representative of three independent experiments.

drug through the production of ROS can induce a depletion of $\mathrm{SH}$ groups. Therefore, we examined the effect of parthenolide on the intracellular levels of protein thiols, free thiols, and free GSH in both MG63 and SK-MEL-28 cells. Time course experiments (Fig. 5A) showed that these levels rapidly diminished with the time so that in MG63 cells at $3 \mathrm{~h}$ of treatment the content of protein thiols was reduced to about $30 \%$ of the control, while free thiols and GSH decreased to only $14 \%$ and $10 \%$, respectively. Similar results were found for SKMEL-28 cells. Low doses of NAC (I50 $\mu \mathrm{M})$ completely prevented the cells of both the lines from the depletion of intracellular thiols (Fig. 5B) and GSH (not shown), while both apocynin and $\mathrm{U} 0 \mathrm{I} 26$ as well as rotenone exhibited partial preventive effects (Fig. 5B).

\section{The effects of parthenolide on NF-KB and JNK activities}

Several lines of evidence suggest that NF-кB induces the expression of target genes that regulate apoptosis and facilitate survival of tumor cells as well as angiogenesis and metastasis. Therefore the inhibition of NF- $\mathrm{B}$ in cancer cells represents one of the major strategies in anticancer therapy (Olivier et al., 2006). Furthermore, it has been established that JNK plays a role in cell death induced by oxidative stress. Finally many authors have shown that parthenolide in several tumor cells inhibits NF- $\mathrm{KB}$ activity and induces JNK activation (Shanmugam et al., 20I0, 20II). On the basis of these considerations we investigated whether the drug exerted any effect on NF- $K B$ and JNK activities in MG63 and SK-MEL-28 cells. Time course experiments showed that $25 \mu \mathrm{M}$ parthenolide markedly decreased the DNA-binding activity of $\mathrm{p} 65$, a component of NF$\kappa \mathrm{B}$, in both cell lines (Fig. 6A). Parthenolide effect was very rapid since after $2 \mathrm{~h}$ of incubation the level of $\mathrm{p} 65$ activity lowered to only $20 \%$ of control.

Moreover, as shown in Figure 6C, parthenolide stimulated in both cell lines phosphorylation and activation of JNK. The effect was observed already at $2 \mathrm{~h}$ and increased at $5 \mathrm{~h}$ of treatment. It is interesting to note that $2 \mathrm{mM}$ NAC completely prevented both the depletion of p65 activity (Fig. 6B) and the activation of JNK (Fig. 6C).

\section{The effect of parthenolide on mitochondrial membrane potential}

It is well known that mitochondrial permeability transition pore (PTP) is located at the inner mitochondrial membrane. Opening of this pore, as a consequence of oxidation of redox-sensitive components, results in mitochondrial permeability transition and dissipation of mitochondrial membrane potential $(\Delta \psi \mathrm{m})$. It is well known that PTP is constituted by adenine nucleotide translocase (ANT) in the inner membrane (Crompton, 1999) and cyclophilin D (Cyp D) in the matrix (Crompton, 1999; Baines et al., 2005). Cyp D induces PTP opening, favoring conformational change dependent on $\mathrm{Ca}^{2+}$, whereas the inhibitor of pore opening cyclosporin $A(C s A)$ interacts with Cyp $D$ reducing sensibility of pore opening to $\mathrm{Ca}^{2+}$ (Chernyak and Bernardi, 1996; Javadov et al., 2009). Furthermore, the voltage-dependent anion channel (VDAC) is located in the outer mitochondrial membrane. Oligomerization of VDAC and the successive interaction with Bax can induce the production of pores permeable to apoptotic factors (Scharstuhl et al., 2009; Shoshan-Barmatz et al., 2010). Such an event can be inhibited by $4,4^{\prime}$-diisothiocyanostilbene-2,2' -disulfonic acid (DIDS), as reported by Keinan et al. (20I0). 
A

MG63

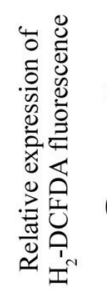

B

MG63
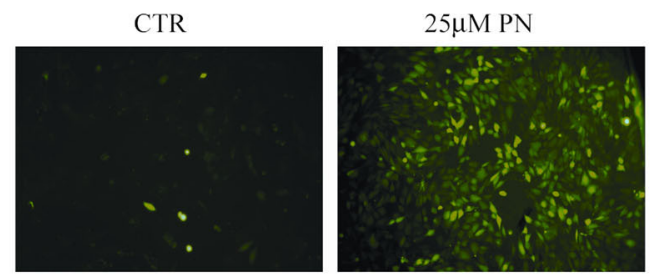

$25 \mu \mathrm{M} \mathrm{PN}+10 \mu \mathrm{M}$ DPI

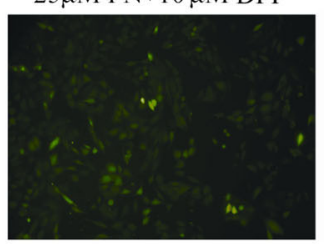

$25 \mu \mathrm{M} \mathrm{PN}+200 \mu \mathrm{M}$ U0126

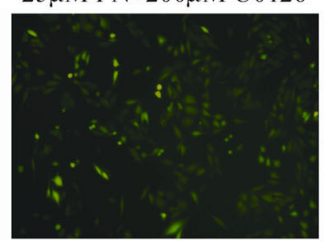

$25 \mu \mathrm{M} \mathrm{PN}+2 \mathrm{mMNAC}$
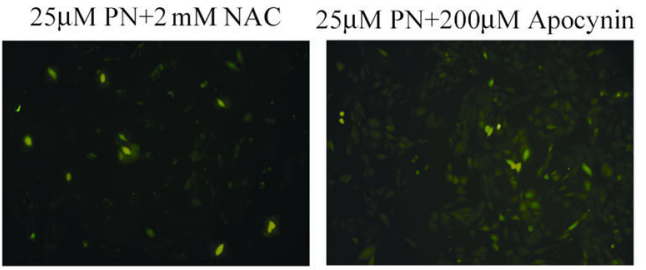

$25 \mu \mathrm{M} \mathrm{PN}+1 \mu \mathrm{M}$ Rotenone

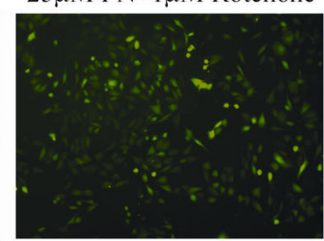

C

MG63

SK-MEL-28
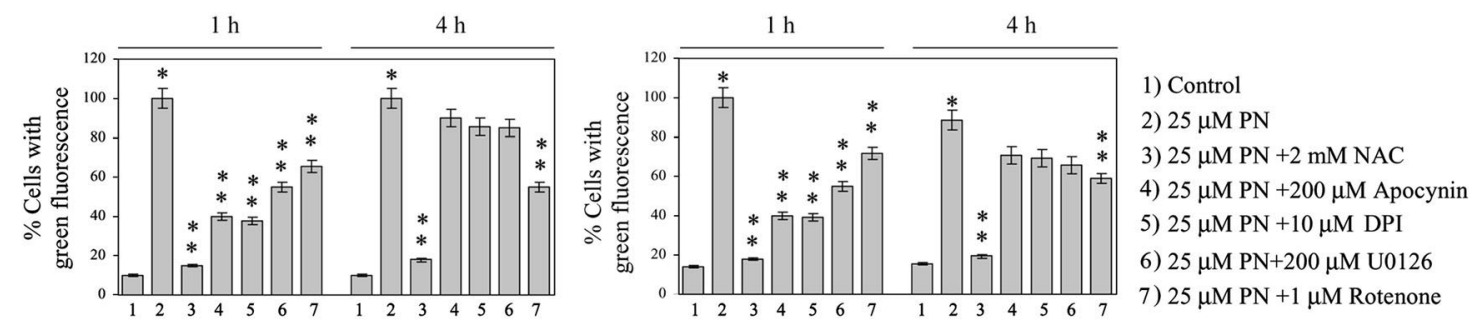

D

MG63

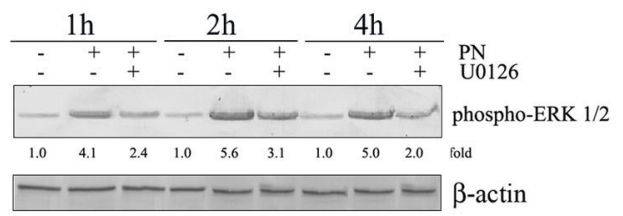

SK-MEL-28

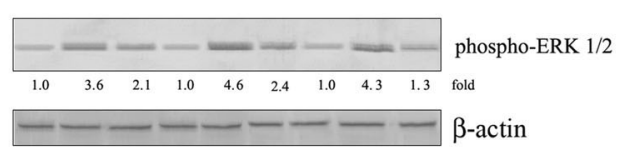

Fig. 4. Parthenolide induces ROS generation. A: Fluorimetric analysis showing the time course of parthenolide-induced ROS generation in MG63 and SK-MEL-28 cells. Cells $\left(6 \times 10^{3} /\right.$ well $)$ were treated with $50 \mu \mathrm{M} \mathrm{H}_{2}$-DCFDA fluorescent signal and then with $25 \mu \mathrm{M}$ parthenolide for various times. Fluorimetric assays were performed in a multiwell fluorescence plate reader at $485 \mathrm{~nm}$ (excitation filter) and $530 \mathrm{~nm}$ (emission filter). B: Images of fluorescence microscopy showing ROS generation determined by parthenolide. MG 63 cells $\left(6 \times 10^{3} /\right.$ well) were treated with $50 \mu \mathrm{M} \mathrm{H} \mathrm{H}_{2}$ DCFDA fluorescent signal and then for I $\mathrm{h}$ with $25 \mu \mathrm{M}$ parthenolide without or with NAC, apocynin, DPI, U0 I 26, or rotenone. Oxidation of the fluorochrome produces green fluorescence, which was visualized with a Leica DC $300 \mathrm{~F}$ microscope at $100 \times$ magnification using a FITC filter. C: Percentages of cells with green fluorescence after treatment of MG63 cells with parthenolide for I or $4 \mathrm{~h}$. The influence of NAC, apocynin, DPI, $\mathrm{U} 0 \mathrm{I} 26$, and rotenone on ROS generation induced by parthenolide. Cells with green fluorescence were counted in three different microscopic fields in each well (three wells per treatment) and expressed as percentage of the total number of cells counted under light microscopy. D: The effect of parthenolide on the level of phospho-ERK I/2. Cells $\left(2 \times 10^{5} /\right.$ well) were treated for various times with parthenolide without or with U0I 26. Cell lysates were immunoblotted and detected with an antibody recognizing phospho-ERK I/2. In (A) and (C) values are the means of three independent experiments $\pm S E .{ }^{*} P<0.01$ versus untreated control. ${ }^{* *} P<0.0$ I versus parthenolide-treated cells. In $(B)$ and $(D)$ the results are representative of three independent experiments. 
A

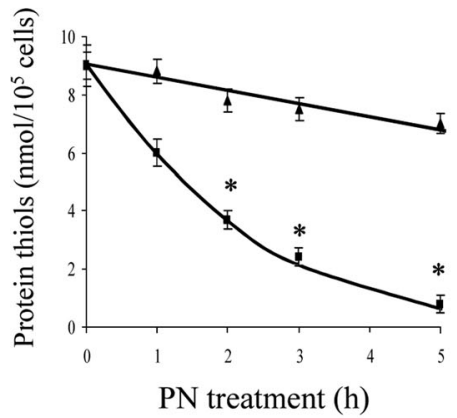

$\mathrm{PN}$ treatment $(\mathrm{h})$
MG63

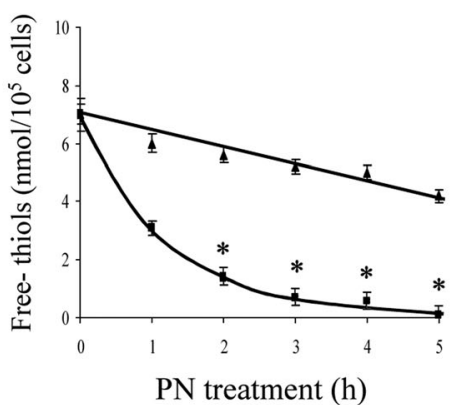

Control

$-25 \mu \mathrm{M}$ PN

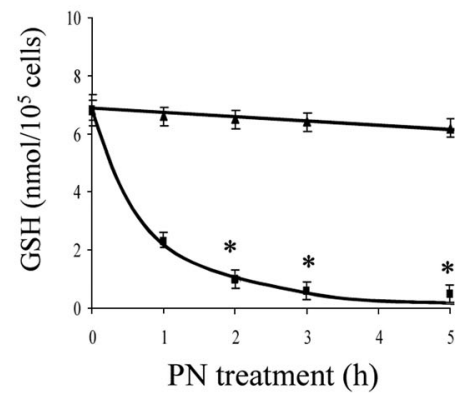

SK-MEL-28

$\rightarrow$ Control

$\rightarrow-25 \mu \mathrm{M}$ PN

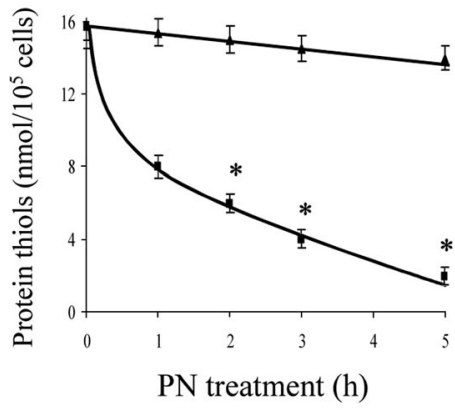

B

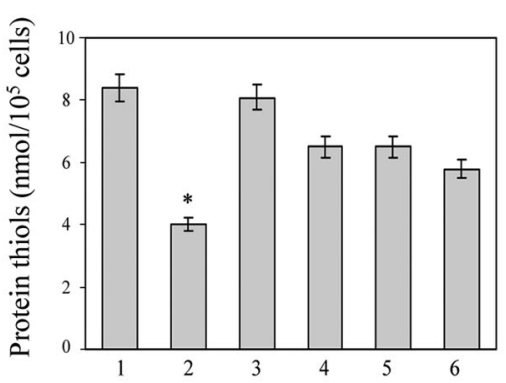

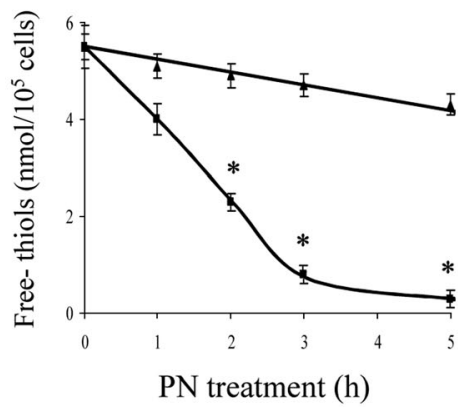

SK-MEL-28

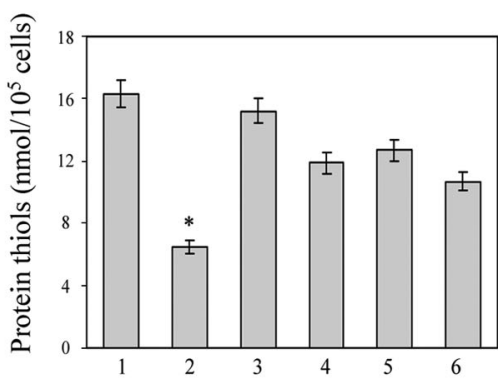

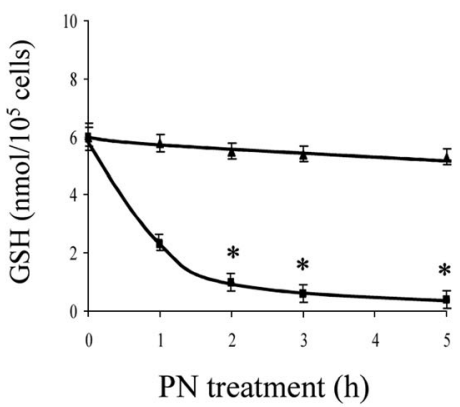

PN treatment $(\mathrm{h})$
1) Control
2) $25 \mu \mathrm{M}$ PN
3) $25 \mu \mathrm{M} \mathrm{PN}+150 \mu \mathrm{M} \mathrm{NAC}$
4) $25 \mu \mathrm{M} P \mathrm{PN}+200 \mu \mathrm{M}$ Apocynin
5) $25 \mu \mathrm{M} \mathrm{PN}+200 \mu \mathrm{M} \mathrm{U} 0126$
6) $25 \mu \mathrm{M} \mathrm{PN}+1 \mu \mathrm{M}$ Rotenone

Fig. 5. Parthenolide induces depletion of intracellular thiols and GSH. A: Time course study of the decreasing effect induced by parthenolide on protein thiols, free thiols, and free GSH in MG63 and SK-MEL-28 cells. Cells ( $2 \times 10^{5} /$ well) were treated for various times with $25 \mu M$ parthenolide. B: The effect of NAC, apocynin, U0I 26, and rotenone on the depletion of protein thiols induced in MG63 and SK-MEL-28 cells by treatment for $2 \mathrm{~h}$ with parthenolide. Protein thiols, free thiols, and free GSH were determined using colorimetric assays, as reported in Methods Section. Values are the means of three independent experiments $\pm S E$. ${ }^{*} P<0.01$ versus untreated control.

The findings that parthenolide stimulated ROS generation and caused depletion of intracellular thiols suggested to us, in agreement with Wen et al. (2002), that the drug can induce dissipation of $\Delta \psi \mathrm{m}$. Therefore, we studied the effect of parthenolide on $\Delta \psi \mathrm{m}$ by using the fluorescent cationic dye JC-I. To this end MG63 and SK-MEL-28 cells were treated with $25 \mu \mathrm{M}$ parthenolide for various times and then with JC-I for additional $15 \mathrm{~min}$. At the end fluorescence was visualized by a Leica microscope. It was possible to observe that after brief treatments (I-3h) JC-I fluorescence shifted from red-orange (J-aggregates) to green (JC-monomer form), indicating dissipation of $\Delta \psi \mathrm{m}$ (Fig. 7A).

Figure 7B shows a time course experiment concerning the effect of parthenolide on MG63 and SK-MEL-28 cells. $\Delta \psi \mathrm{m}$ was expressed as a ratio between cells with brilliant red fluorescence (J-aggregates) and cells with brilliant green fluorescence (JC-I monomers) (red/green fluorescence). In the presence of parthenolide this ratio rapidly lowered to about $20 \%$ of control at I h and $10 \%$ at $2 \mathrm{~h}$ of treatment. Such an effect was prevented by the addition of $2 \mathrm{mMNAC}$ (Fig. 7C). Moreover $10 \mu \mathrm{M}$ CsA partially prevented parthenolide- 
$\mathbf{A}$

MG63

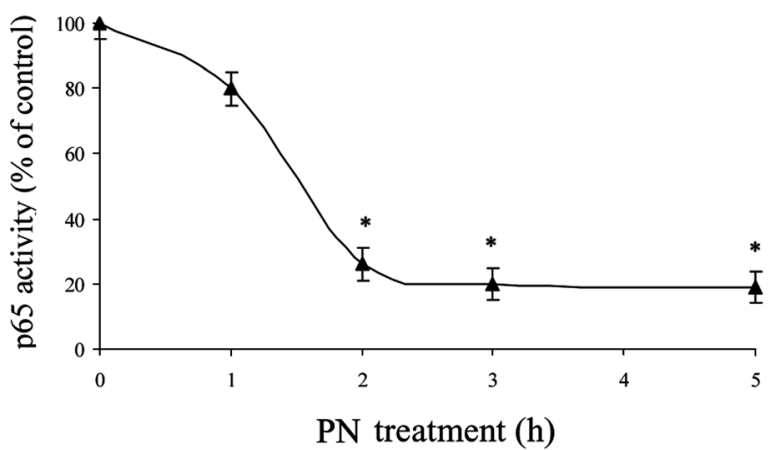

SK-MEL-28

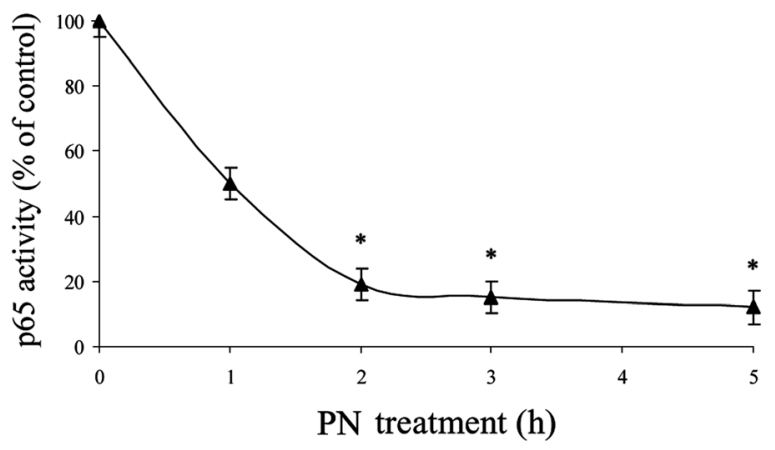

B MG63

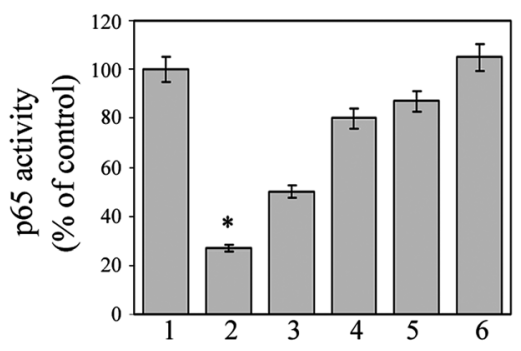

C

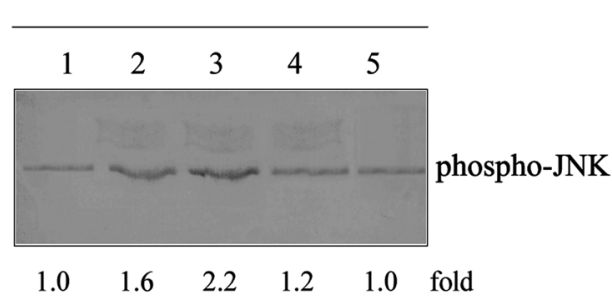

$\beta$-actin

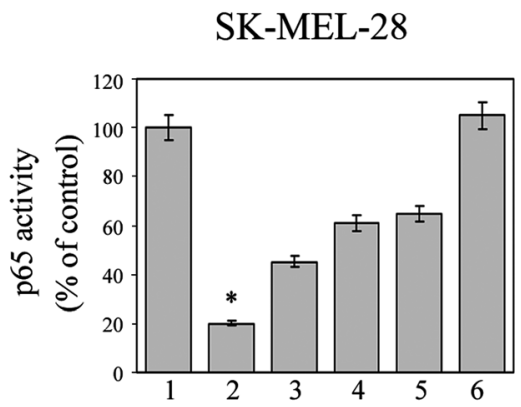

1) Control

2) $25 \mu \mathrm{M}$ PN

3) $25 \mu \mathrm{M} \mathrm{PN}+0.2 \mathrm{mM} \mathrm{NAC}$

4) $25 \mu \mathrm{M} \mathrm{PN}+0.5 \mathrm{mM} \mathrm{NAC}$

5) $25 \mu \mathrm{M} \mathrm{PN}+1.0 \mathrm{mM} \mathrm{NAC}$

6) $25 \mu \mathrm{M} \mathrm{PN}+2.0 \mathrm{mM} \mathrm{NAC}$

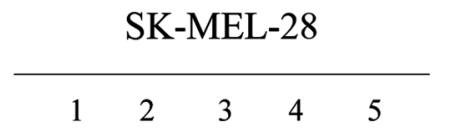

1) Control

2) $25 \mu \mathrm{MPN} 2 \mathrm{~h}$

3) $25 \mu \mathrm{M}$ PN $5 \mathrm{~h}$

4) $25 \mu \mathrm{M} \mathrm{PN}+0.5 \mathrm{mM} \mathrm{NAC} 2 \mathrm{~h}$

5) $25 \mu \mathrm{M} \mathrm{PN}+2 \mathrm{mM} \mathrm{NAC} 2 \mathrm{~h}$

Fig. 6. The effects of parthenolide on NF-KB and JNK activity. A: Time course study of the parthenolide effect on DNA-binding activity of p65, a member of NF-kB. Cells were treated for various times with $25 \mu M$ parthenolide. The binding was quantified in nuclear extracts of MG63 and SK-MEL-28 cells by an ELISA assay as reported in Methods Section. B: NAC prevented parthenolide effect on p65 binding. Cells were treated for $2 \mathrm{~h}$ with parthenolide and various doses of NAC. C: Parthenolide stimulated phosphorylation of JNK, while NAC prevented this effect. MG63 and SK-MEL-28 cells $\left(2 \times 10^{5} /\right.$ well $)$ were treated for 2 or $5 \mathrm{~h}$ with $25 \mu \mathrm{M}$ parthenolide without or with NAC. At the end cell extracts were prepared and submitted to western blotting analysis. Detection was performed by using an antibody against phospho-JNK. In (A) and (B) values are the means of three independent experiments $\pm S E$. ${ }^{*} P<0.0$ I versus untreated control. In $(C)$ the results are representative of three independent experiments.

induced depolarization, increasing the ratio "red/green fluorescence" from $10 \%$ to $50 \%$ of control, while a minor effect was exerted by $300 \mu$ M DIDS. These results (Fig. 7A,C) strongly suggested that parthenolide-induced depolarization can be considered as a consequence of events primarily determined at the inner mitochondrial membrane.

Because it has been suggested that mitochondrial $\mathrm{Ca}^{2+}$ accumulation plays a role in the induction of PTP opening, we examined the effect of RU360, a selective inhibitor of the mitochondrial calcium uptake system (Garcia-Rivas et al., 2006). As reported in Figure 7C, $10 \mu$ M RU360 partially prevented parthenolide-induced depolarization. Therefore, we concluded that dissipation of $\Delta \psi \mathrm{m}$ was favored by calcium overload.
Finally, parthenolide effect on $\Delta \psi \mathrm{m}$ was not prevented by caspase inhibitors (not shown).

\section{The effects of parthenolide on ATP and cytosolic calcium level}

The effect exerted by $25 \mu \mathrm{M}$ parthenolide on the intracellular ATP content was studied in both MG63 and SK-MEL-28 cells during $15 \mathrm{~h}$ of treatment (Fig. 8A). Until the fifth hour of treatment ATP level was not modified by the drug. Then ATP content progressively decreased and at $15 \mathrm{~h}$ of treatment the level of ATP, expressed as nmol/ $100 \mu \mathrm{g}$ of protein, lowered in MG63 cells from the value of 3.5 in the untreated control to 0.7 in treated cells $(-80 \%)$. Similarly in SK-MEL-28 cells ATP level 


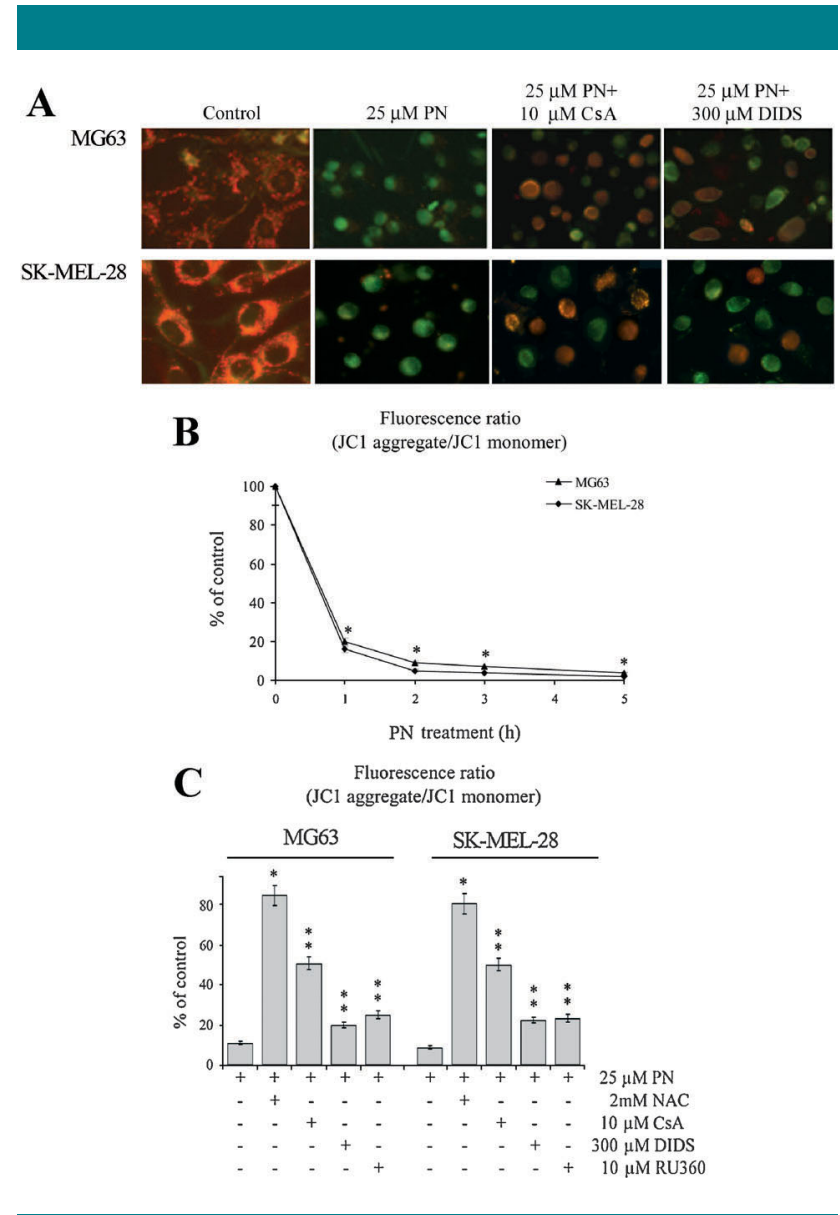

Fig. 7. The effects of parthenolide on mitochondrial membrane potential. A: Parthenolide induced mitochondrial depolarization in MG63 and SK-MEL-28 cells. Cells $\left(6 \times 10^{3} /\right.$ well) were treated for $2 \mathrm{~h}$ with $25 \mu \mathrm{M}$ parthenolide without or with CsA or DIDS. At the end the fluorochrome JC-I was added for additional $15 \mathrm{~min}$. Depolarization was indicated by the shift of fluorescence from red-orange to greenish. Fluorescent cells were visualized with a Leica DC 300F microscope at $200 \times$ magnification with fluorescent filters for FITC and rhodamine. Application of CsA or DIDS partially inhibited the effect of parthenolide. B: The effect exerted in MG63 cells by parthenolide on mitochondrial membrane potential, expressed as a ratio of J-aggregate to JC-monomer (red/green fluorescence). Time course study of the effect induced by $25 \mu \mathrm{M}$ parthenolide. C: NAC, CsA, DIDS, and RU360 partially prevented the effect exerted by treatment for $\mathbf{2} \mathrm{h}$ with parthenolide. In (A) the results are representative of three independent experiments. In (B) and (C) values are the means of three independent experiments $\pm S E$. ${ }^{*} \boldsymbol{P}<0.01$ versus untreated control. ${ }^{* *} \boldsymbol{P}<0.01$ versus parthenolidetreated cells.

diminished from the value of 2.2 in the control to only 0.4 in treated cells (-82\%).

As shown in Figure 8B, treatment with $25 \mu \mathrm{M}$ parthenolide induced a remarkable increase in the level of cytosolic calcium both in MG63 and SK-MEL-28 cells. The effect was very rapid because was observed already at I $\mathrm{h}$ of treatment.

Parthenolide induces mitochondrial release of cytochrome $c$ and decreases the expression of pro-caspases-3 and 8

A consequence of $\Delta \psi \mathrm{m}$ dissipation in the mechanism of apoptosis is the release from mitochondria of some proteins, such as cytochrome c, AIF or Smac/DIABLO. It is well known that cytochrome $c$, when is released into the cytosol interacts with APAF-I, pro-caspase- 9 and dATP to form the apoptosome (Reubold and Eschenburg, 20I2). This complex activates caspase-9, which in turn activates the effector caspase-3. Since parthenolide caused disruption of mitochondrial membrane potential, we performed some experiments to ascertain whether the drug stimulated the release of cytochrome $c$. MG63 and SK-MEL-28 cells were treated for $3 \mathrm{~h}$ with $25 \mu \mathrm{M}$ parthenolide. At the end the cells were homogenized and the subcellular fractions were prepared as reported in Methods. By means of an ELISA assay it was possible to demonstrate that parthenolide increased the content of cytochrome $c$ in the cytosolic fraction while a concomitant decrement was observed in the mitochondria (Fig. 9A).

We investigated by means of western blotting analysis whether parthenolide exerted some effects on the expression of pro-caspases and on the production of their active forms. As shown in Figure 9B, parthenolide treatment markedly decreased in both cell lines the level of both pro-caspase- 8 and pro-caspase-3. These effects were already observed at $3 \mathrm{~h}$ of treatment and became more consistent at $5 \mathrm{~h}$. Instead the level of pro-caspase- 9 was not modified. Antibodies employed for this analysis detect both the full-length forms of caspases and the active fragments resulting from cleavage. However, for the three caspase activities it was not possible to observe the production of the cleaved and active forms not only at 3 and $5 \mathrm{~h}$ (Fig. 9B), but also when the treatment was prolonged to 10 and I5 h (not shown).

\section{Parthenolide induces mitochondrial release of AIF and its co-localization with DNA}

It is well known that AIF is a caspase-independent death effector (Baritaud et al., 20I0), which after mitochondrial release translocates to the nucleus, where induces CC and DNA fragmentation (Jin and El-Deiry, 2005). Therefore, we performed some experiments in order to ascertain whether parthenolide stimulates the release of AIF from mitochondria. Western blotting analysis showed that after $3 \mathrm{~h}$ of treatment with $25 \mu M$ parthenolide AIF level decreased in the mitochondria while it increased in the nuclear fraction (Fig. 10A). These results suggested that parthenolide determined as a consequence of mitochondrial depolarization the release of both cytochrome $c$ and AIF.

Then we investigated whether parthenolide treatment stimulated co-localization of AIF with DNA. The cells were stained with Hoechst 33342 for DNA and with an anti-AIF antibody suitable for the detection of endogenous AIF. In untreated cells AIF was clearly localized in extranuclear sector, whereas in parthenolide-treated cells AIF migrated to the nucleus and co-localized with areas of condensed chromatin. Figure IOB shows co-localization of AIF with DNA, which was observed after treatment for $3 \mathrm{~h}$ with $25 \mu \mathrm{M}$ parthenolide either in MG63 and SK-MEL-28 cells. These results were not modified by the addition of $100 \mu M$ z-VAD-fmk (not shown).

Transfection of cells with AIF siRNA reduces the cytotoxic effects induced by parthenolide

In order to ascertain whether AIF takes part in the cytotoxic effect exerted by parthenolide we have transiently transfected both MG63 and SK-MEL-28 cells with AIF siRNA. After transfection for $6 \mathrm{~h}$ the incubation was protracted for other I8 h. Western blotting analysis (Fig. IIA) revealed that this procedure caused down-regulation of AIF, which diminished by about $70 \%$ in both MG63 and SK-MEL-28 cells, while AIF level remained constant in the control cells, which were transfected with scramble siRNA.

When AIF-silenced cells of both the lines were treated for $2-4 \mathrm{~h}$ with $25 \mu \mathrm{M}$ parthenolide a minor number of cells ( -40 to $50 \%$ ) with condensed chromatin (CC cells) was 
A

MG63

SK-MEL-28

\section{$\neg$ Control \\ $\rightarrow-25 \mu \mathrm{M}$ PN}

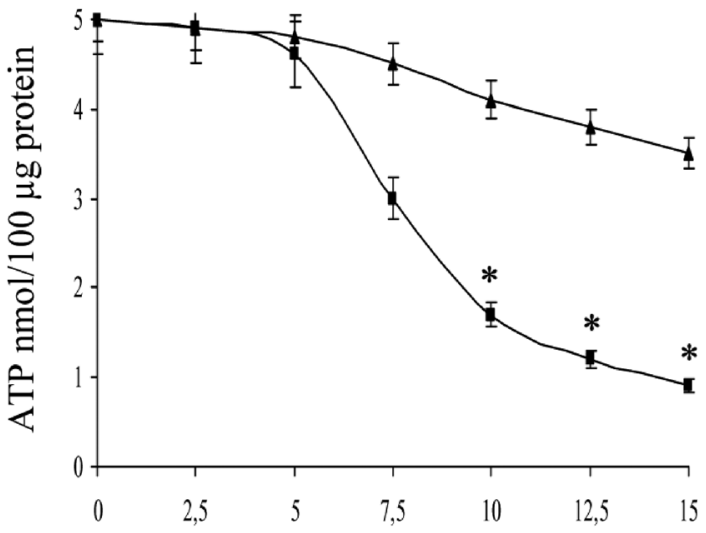

PN treatment (h)

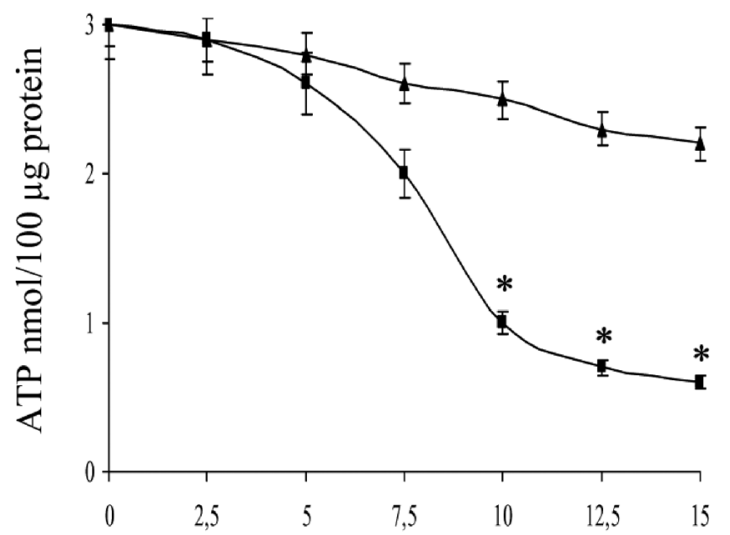

PN treatment (h)

B

\section{$25 \mu \mathrm{M}$ PN}

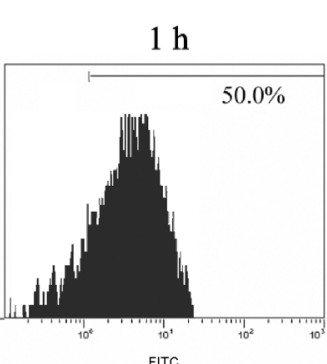

FITC

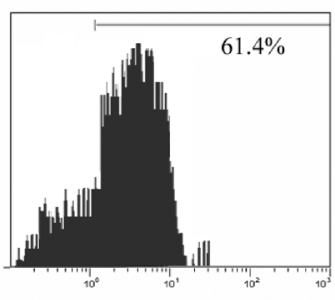

FITC

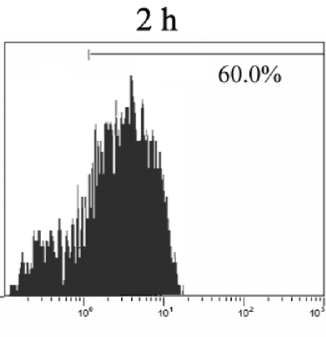

FITC

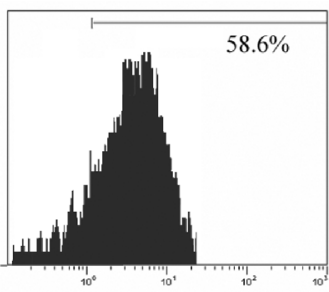

FITC
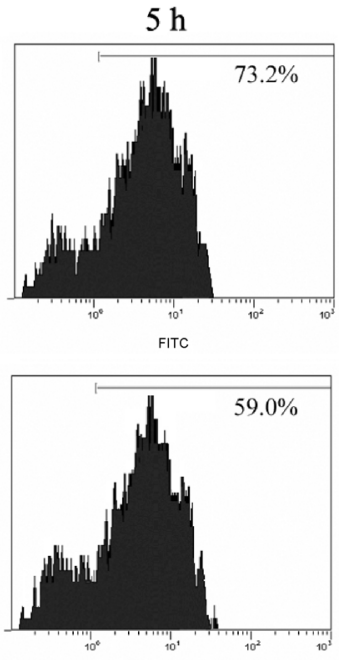

FITC

Fig. 8. The effects of the parthenolide on the levels of ATP and intracellular $\mathrm{Ca}^{2+}$. A: Parthenolide induced depletion of ATP level. Time course study of the parthenolide effect on the intracellular content of ATP both in MG63 and SK-MEL-28 cells. Cells ( $2 \times 10^{5} /$ well) were treated with $25 \mu$ M parthenolide for various times. At the end extracts were prepared and ATP was assayed by means of a colorimetric procedure. B: Parthenolide increased intracellular $\mathrm{Ca}^{2+}$ level. MG63 and SK-Mel28 cells $\left(2 \times 10^{5} /\right.$ well $)$ were treated with $25 \mu$ parthenolide for I, 2 , or 5 h. At the end cells were loaded with Fluo-3 AM for 60 min and then immediately analyzed using flow cytometry. In (A) values are the means of three independent experiments $\pm S E$. ${ }^{*} P<0.01$ versus untreated control. In (B) the results are representative of three independent experiments.

observed in comparison with control cells transfected with a scramble siRNA (Fig. IIB). Similarly after longer periods of treatment $(10-15 h)$ the percentages of cells exhibiting PF diminished in AIF-silenced cells with respect to the controls (Fig. IIB). The results suggested that AIF can be considered as an effective mediator of parthenolide action.

\section{Discussion}

Although many authors have investigated about the antitumor action of parthenolide, the modalities through which this drug induces cell death are not clearly defined at the moment.

It is well known that cell death can be determined by two different mechanisms, apoptosis or necrosis. Apoptosis (Jin and El-Deiry, 2005) is an active process of programmed cell death, which can be triggered in tumor cells by a number of different stimuli, such as stimulation of death receptors, DNA damage and oxidative stress. Apoptosis displays cell shrinkage, CC and fragmentation, production of apoptotic bodies, and sequential activation of multiple caspases. Instead classic necrosis (Golstein and Kroemer, 2007) is a passive process, 


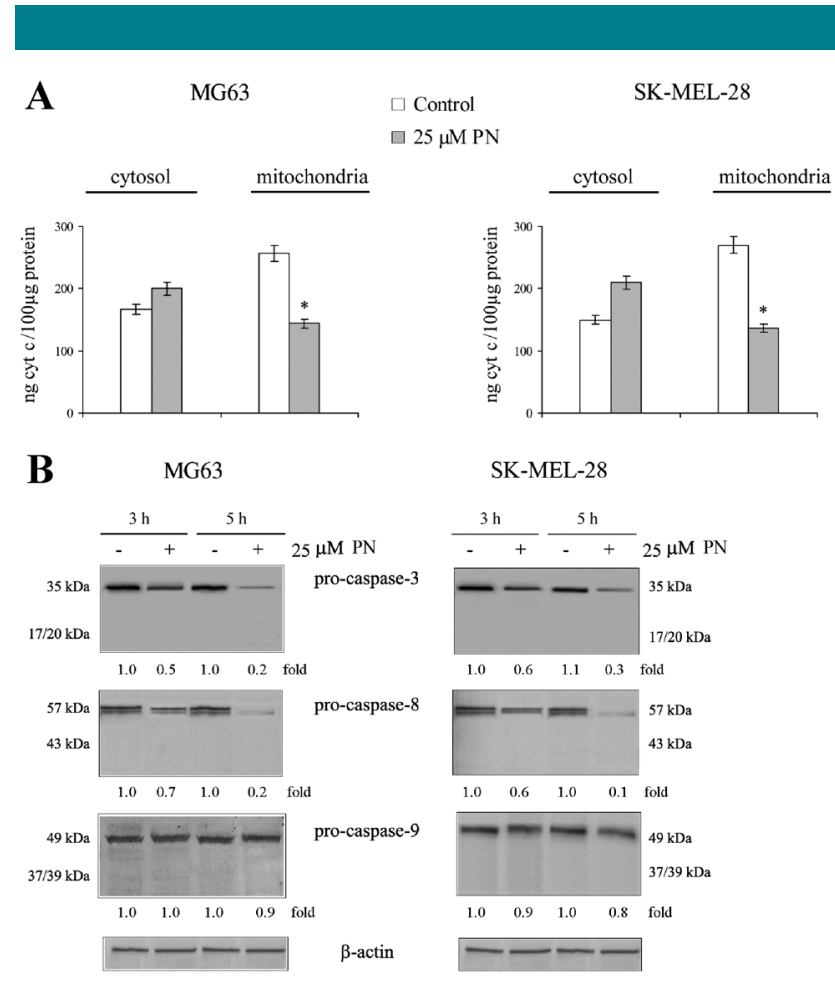

Fig. 9. A: Parthenolide induces the release of cytochrome c from mitochondria. MG63 and SK-MEL-28 cells $\left(7 \times 10^{6} / 100-\mathrm{mm}\right.$ culture dish) were treated for $3 \mathrm{~h}$ with $25 \mu \mathrm{M}$ parthenolide and then homogenized with a Dounce homogenizer. Subcellular fractionation was performed as reported in Methods Section. Cytochrome c content was assayed in mitochondrial and cytosolic fractions by means of an ELISA procedure. B: The effect of parthenolide on pro-caspase expression. MG63 and SK-MEL-28 cells $\left(2 \times 10^{5} /\right.$ well) were treated for 3 and $5 \mathrm{~h}$ with $25 \mu \mathrm{M}$ parthenolide. At the end extracts were prepared and submitted to western blotting analysis in order to ascertain the level of pro-caspases-3, -8 , and -9 and their possible cleavage forms. In (A) values are the means of three independent experiments \pm SE. ${ }^{*} \boldsymbol{P}<0.0$ I versus untreated control. In $(B)$ the results are representative of three independent experiments.

characterized by disruption of cellular plasma membrane and extensive cellular swelling. Recently it has been shown that also necrosis can be considered as a programmed mechanism of cell death (Artus et al., 20 I0; Baritaud et al., 20I0), but independent on caspase activities. However, at the moment a distinction between apoptosis and necrosis on the basis of the dependence on caspase activities is not certain, because other caspaseindependent mechanisms of programmed cell death have been recently described, some of which exhibit necrotic-like aspects, whereas others show apoptotic-like characteristics (Tait and Green, 2008).

Although previous studies report that parthenolide induces cell death in a number of tumor cells by a caspase-dependent mechanism (Steele et al., 2006; Liu et al., 2010), our article shows for the first time that parthenolide stimulated in human osteosarcoma MG63 and melanoma SK-MEL-28 cells a caspaseindependent mechanism. In particular parthenolide induced in the first phase of treatment $(0-5 \mathrm{~h})$ in most of cells of both the lines condensation of chromatin while only a few cells were PIpositive. Moreover, cells assumed a rounded shape, showed a substantial reduction of their volume and appeared detached from substrate. In the second phase of treatment (5-I5h) a progressive increase in the percentages of $\mathrm{Pl}$-positive cells was observed, suggesting that extensive damage of cellular plasma

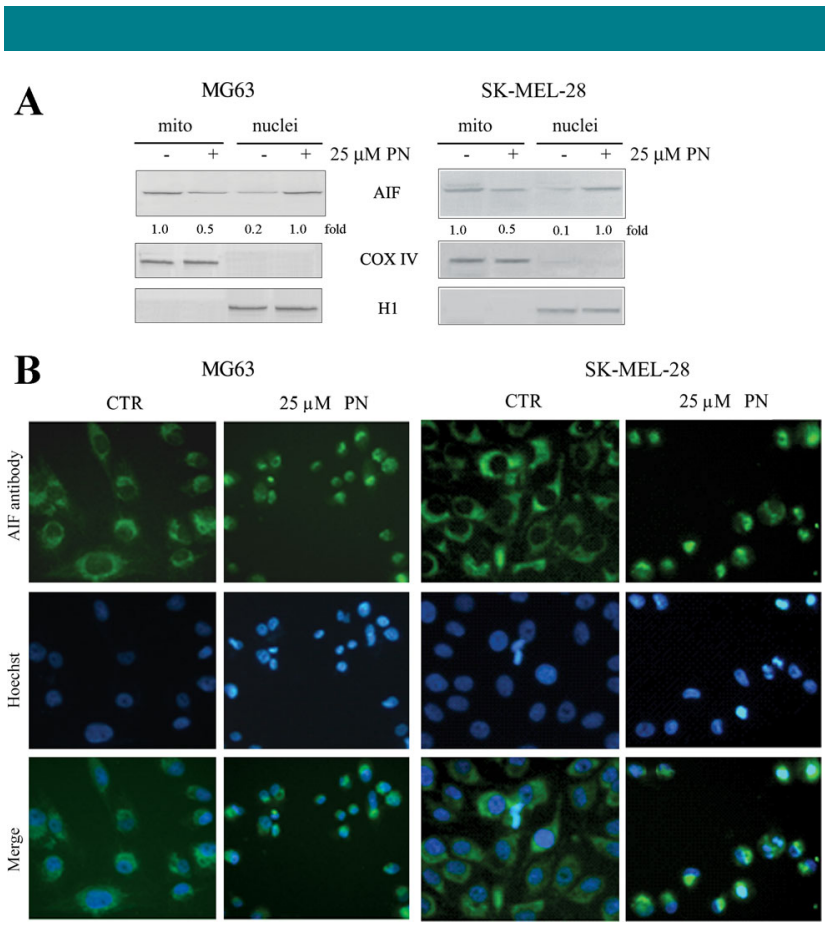

Fig. 10. A: Parthenolide induces the release of AIF from mitochondria. MG63 and SK-MEL-28 cells $\left(7 \times 10^{6} / 100-\mathrm{mm}\right.$ culture dish) were treated for $3 \mathrm{~h}$ with $25 \mu \mathrm{M}$ parthenolide and then homogenized. Subcellular fractions were prepared as reported in Methods Section. AIF was analyzed by western blotting using $30 \mu \mathrm{g}$ of proteins of each fraction. B: Parthenolide stimulates translocation of AIF from the mitochondria to the nuclei and co-localization with DNA. MG63 and SK-MEL-28 cells $\left(6 \times 10^{3} /\right.$ well) were treated for $3 \mathrm{~h}$ with $25 \mu M$ parthenolide and subjected to immunofluorescence analysis of AIF distribution using anti-AIF antibody and FITCconjugated secondary antibody (green fluorescence). Nuclei were stained with Hoechst 33342 (blue fluorescence). The nuclear translocation of AIF was shown by the merge of AIF and nuclear staining. Fluorescent cells were visualized with a Leica DC 300F microscope at $200 \times$ magnification with fluorescent filters for FITC and DAPI for AIF and Hoechst, respectively. In (A) and (B) the results are representative of three independent experiments.

membranes occurred only after long periods of treatment. All these events depended on oxidative stress because were prevented by NAC, whereas they were caspase-independent since z-VAD-fmk and other caspase inhibitors were unable to modify them.

Our results suggest that oxidative stress played a central role in both cell lines in the mechanism of parthenolide action. The drug strongly induced ROS generation already in the first $2 \mathrm{~h}$ of treatment. Such an effect, in accordance with Sun et al. (20l0), was primarily dependent on the activation of NOX, since it was efficaciously prevented by apocynin and DPI. The role of mitochondrial respiratory chain was predominant at $4 \mathrm{~h}$ of treatment, when rotenone resulted to be the best inhibitor of parthenolide effect.

In the first hours of treatment ROS generation was responsible for a series of events which caused toxic effects in the cells. In particular parthenolide induced in both cell lines a marked depletion of the intracellular level of free thiols, protein thiols, and free GSH. Furthermore, the drug reduced cellular adhesion to the matrix, favoring the detachment and the successive shrinkage of the cells; inhibited the binding of p65, a component of NF- $\mathrm{B}$, to DNA and caused phosphorylation and activation of JNK. The conclusion that all these events were determined by oxidative stress was supported by the evidence 


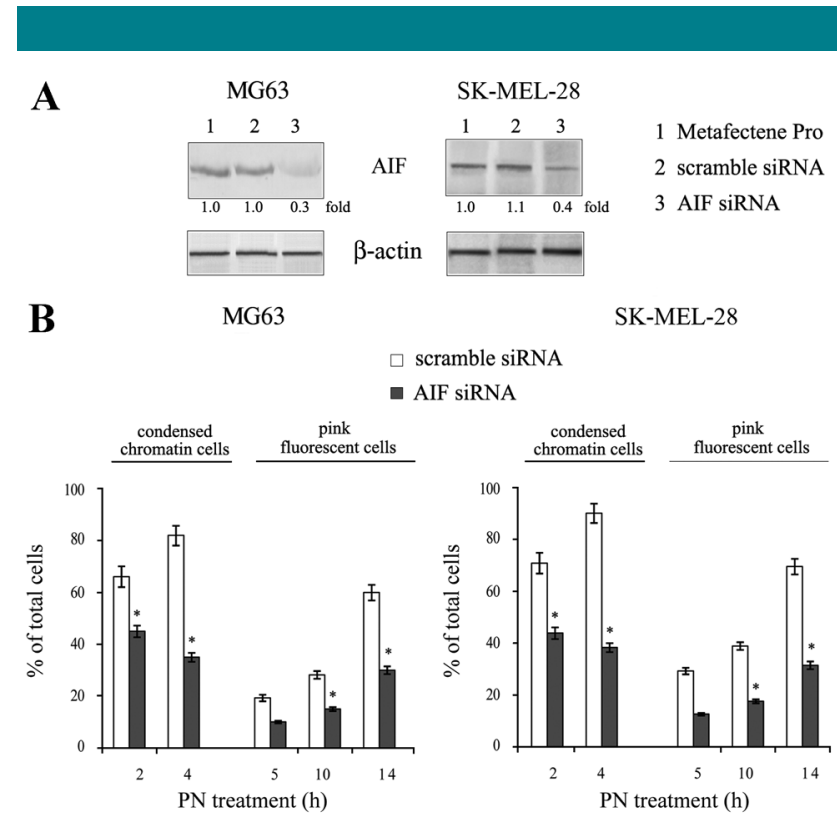

Fig. I I. Depletion of AIF prevents the cytotoxic effect of parthenolide. MG63 and SK-MEL-28 cells were transfected with $80 \mathrm{nM}$ AIF siRNA, as reported in Methods Section, and compared with cells transfected with $80 \mathrm{nM}$ scramble siRNA. A: Western blotting analysis showing depletion of AIF in silenced cells. B: Depletion of AIF diminished parthenolide effect on the production of both cells with condensed chromatin (CC cells) and with pink fluorescence (PF cells). AIF-silenced cells and control cells transfected with scramble siRNA were treated for various times with $25 \mu \mathrm{M}$ parthenolide. At the end the percentages of $C C$ and PF cells were determined with respect to the total number of cells. In $(A)$ the results are representative of three independent experiments. In (B) values are the means of three independent experiments $\pm S E$. ${ }^{*} P<0.01$ versus scramble siRNA-transfected cells.

that they were prevented by the addition of anti-oxidants. Moreover our conclusion was in agreement with the following considerations: First, it is well known that ROS can oxidize protein thiols (Zhang et al., 2004) while GSH depletion can occur as a consequence of the involvement of GSH peroxidase activity in the scavenge of ROS and other free radicals. Second, ROS generation has been shown to inhibit adhesion of mesenchymal stem cells (Song et al., 20I0) and to induce cellular shrinkage of Ehrlich ascites cells by activating $\mathrm{KCl}$ cotransport (Lambert et al., 2009). Third, it has been suggested that ROS generated by parthenolide can disrupt the NF- $\kappa B$ DNA binding by either direct reactions or altering intracellular redox (Shanmugam et al., 20I0). Fourth, ROS can mediate JNK activation inducing either apoptosis or necrosis (Shen and Liu, 2006; Shanmugam et al., 2010).

In addition it is interesting to note that oxidative stress and in particular oxidation of both protein thiols (Petronilli et al., 1994; McStay et al., 2002) and GSH (Costantini et al., 1996; Halestrap et al., 1998) are involved in the control of mitochondrial membrane potential, favoring the opening of the PTP in the inner mitochondrial membrane with the consequent mitochondrial depolarization. In accordance our results show that mitochondrial depolarization was completely abrogated by NAC.

PTP plays a crucial role in the regulation of the decisive events for the fate of the cells occurring in mitochondria, such as production of ATP, calcium homeostasis, and programmed cell death. PTP opening permits the passage of solutes with low molecular weight into the matrix. Consequently the osmotic pressure increases leading to the swelling of the matrix with the rupture of the outer membrane and the passage of apoptotic factors into the cytoplasm (Keinan et al., 2010). Instead the inner membrane remains intact since it is larger than the outer membrane. Furthermore, apoptotic factors can be also released through VDAC after its oligomerization and interaction with Bax. In this article mitochondrial membrane potential $(\Delta \psi \mathrm{m})$ was studied by using the fluorescent dye JC-I, which undergoes polymerization when $\Delta \psi \mathrm{m}$ is high. Our results showed that parthenolide caused depolarization of mitochondrial membrane. The effect was very rapid, since after $\mathrm{I}-2 \mathrm{~h}$ of treatment, the ratio "red fluorescence to green fluorescence," which is in correlation with the polymerization degree of JC-I, lowered to only 10-20\% of the control value. Mitochondrial depolarization was prevented by CsA, an inhibitor of PTP opening (Javadov et al., 2009). Therefore PTP opening with the consequent rupture of the outer mitochondrial membrane seemed to be an important event in the depolarization of mitochondrial membrane induced by parthenolide. However, we concluded that also VDAC can be involved in the dissipation of membrane potential, since depolarization was also reduced by the inhibitor of VDAC DIDS, although DIDS effect was minor than that observed with CsA.

Furthermore our results suggest that a role in mitochondrial depolarization is also exerted by calcium overload since the loss of $\Delta \psi \mathrm{m}$ was partially prevented by RU360, an inhibitor of the influx of $\mathrm{Ca}^{2+}$ into mitochondria.

It has been suggested that the extent of PTP opening is fundamental to determine the modality of cell death. In fact transient opening could be responsible for mitochondrial swelling and the release of apoptotic factors, such as cytochrome $\mathrm{c}$ and AIF, while ATP concentration can be not affected. Instead extensive and persistent opening could lead to a substantial ionic disturbance with the loss of ATP, activation of degradative enzymes, and cellular necrosis (McStay et al., 2002). Our results demonstrate that after treatment with parthenolide for $3-5 \mathrm{~h}$ most of cells were positive to Hoechst and showed CC, while ATP concentration was not modified. Instead mitochondrial depolarization for longer periods of treatment $(10-15 \mathrm{~h})$ induced the fall in ATP content and consequently the predominance of the necrotic signs. Therefore most of cells exhibited PF, since they were positive to both Hoechst and PI.

An important consequence of parthenolide-induced depolarization of mitochondrial membrane consists in the release of cytochrome $\mathrm{c}$ and/or AIF. Cytochrome $\mathrm{c}$ is usually the responsible for the activation of caspase-dependent apoptosis, while AIF mediates the activity of caspaseindependent program. This article shows that treatment with parthenolide for $3 \mathrm{~h}$ induced the release from mitochondria of both cytochrome c and AIF. Cytochrome c, when is released into the cytosol, causes the production of apoptosome with the consequent activation of the initiator caspase-9, which in turn stimulates the downstream caspase cascade. However, in our experimental conditions although cytochrome $\mathrm{c}$ was released from mitochondria the activation of caspase cascade did not occur. This conclusion is based on the following findings: western blotting analysis showed that parthenolide decreased the level of pro-caspases- 8 and -3 already after brief periods of treatment, while the cleaved and active forms of caspases-8, -9, and -3 were not produced during the entire treatment; the decrement of ATP caused by parthenolide in the second period is in contrast with the production of apoptosome; z-VAD-fmk and other caspase inhibitors did not exert any effect on the cytotoxic action of parthenolide. In addition our results are in agreement with other reports showing that caspase activities are strongly inhibited by oxidative stress (Samali et al., 1999). Finally it has been reported that ERK I/2, a kinase which is 
activated by parthenolide, can suppress caspase- 9 activity by direct phosphorylation of an inhibitory site, Thr I 25 (Allan et al., 2003). Therefore, all these considerations led us to the conclusion that parthenolide induces cell death through a caspase-independent mechanism.

Differently from cytochrome c, AIF has been shown to induce a caspase-independent mechanism in many circumstances. However it is uncertain at the moment whether AIF is present in the intermembrane space (Sevrioukova, 20I I) or is inserted in the inner mitochondrial membrane (Arnoult et al., 2002; Otera et al., 2005). In the first case permeabilization of the outer membrane could directly cause AIF release from mitochondria, while in the second case the cleavage of the protein by calpains is needed before AIF is released from mitochondria (Polster et al., 2005). In both the cases AIF after its release translocates to the nucleus where it contributes to CC, high molecular weight DNA fragmentation, and nuclear shrinkage (Susin et al., 2000; Dawson and Dawson, 2004; Hong et al., 2004). Taken together our data strongly suggest that AIF can be considered as an important mediator of cell death induced by parthenolide. This conclusion is based on the following evidences: First, immunofluorescence permitted to ascertain that after parthenolide treatment AIF co-localized in the nuclei with condensed chromatin. Second, down-regulation of AIF expression by specific siRNA markedly reduced the cytotoxic effectiveness of parthenolide; in fact parthenolide induced CC and fragmentation in a percentage of AIF-silenced cells, which was much lower than that ascertained in the control. A similar observation was also made for the cells showing necrotic-like aspects, which appeared in the second phase of treatment. Third, z-VAD-fmk was unable to prevent both parthenolide-induced cell death and AIF translocation to the nucleus. In addition observation that parthenolide stimulated mitochondrial calcium uptake is in accordance with the finding that $\mathrm{Ca}^{2+}$ can induce calpain-dependent cleavage of AIF from the inner membrane (Norberg et al., 2008).

The results reported in this article demonstrate that parthenolide rapidly caused dissipation of $\Delta \psi \mathrm{m}$ through ROS generation. Depolarization of mitochondrial membrane induced translocation of AIF to the nucleus (Pardo et al., 200I) with the consequent condensation of chromatin and nuclear shrinkage. These events occurred in the first phase of treatment $(0-5 \mathrm{~h})$. In the second phase of treatment $(5-15 \mathrm{~h})$ the content of ATP progressively lowered, reaching very low values at $12-15 \mathrm{~h}$. Therefore, necrotic aspects became gradually prevalent and a high percentage of cells died for necrosis.

In conclusion this article shows that parthenolide induces cell death in human MG63 and SK-MEL-28 cells by activating a caspase-independent mechanism, which is mediated by AlF. In particular AIF seems to be responsible not only for CC but also for necrotic events. This is in accordance with recent reports showing that AIF plays a key role in programmed necrosis by its ability to organize a DNA-degrading complex (Artus et al., 2010; Baritaud et al., 20I0). Therefore, our article sheds new light on the mechanism by which parthenolide induced death of tumor cells and assigns to AIF the central role in the execution of this caspase-independent mechanism of programmed cell death.

\section{Acknowledgments}

This work was supported by the grant "Innovative Research Project," 2007, University of Palermo, Italy. D. Carlisi is a recipient of a grant by “Ministero dell'Istruzione, dell'Università e della Ricerca” (MIUR).

\section{Literature Cited}

Allan LA, Morrice N, Brady S, Magee G, Pathak S, Clarke PR. 2003. Inhibition of caspase-9 through phosphorylation at Thr I25 by ERK MAPK. Nat Cell Biol 5:647-654.
Arnoult D, Parone P, Martinou JC, Antonsson B, Estaquier J, Ameisen JC. 2002. Mitochondria release of apoptosis-inducing factor occurs downstream of cytochrome $c$ release in response to several proapoptotic stimuli. J Cell Biol I59:923-929.

Artus C, Boujrad H, Bouharrour A, Brunelle MN, Hoos S, Yuste V], Lenormand P, Rousselle JC, Namane A, England P, Lorenzo HK, Susin SA. 2010. AIF promotes chromatinolysis and caspase-independent programmed necrosis by interacting with histone $\mathrm{H} 2 \mathrm{AX}$. EMBO f 29:1585-1599.

Baines CP, Kaiser RA, Purcell NH, Blair NS, Osinska H, Hambleton MA, Brunskill EW, Sayen MR, Gottlieb RA, Dorn GW, Robbins J, Molkentin JD. 2005. Loss of cyclophilin D reveals a critical role for mitochondrial permeability transition in cell death. Nature 434:658-662.

Baritaud M, Boujrad H, Lorenzo HK, Krantic S, Susin SA. 2010. The missing link in AIFmediated caspase independent programmed necrosis. Cell Cycle 9:3166-3173.

Batandier C, Guigas B, Detaille D, El-Mir MY, Fontaine E, Rigoulet M, Leverve XM. 2006. The ROS production induced by a reverse-electron flux at respiratory-chain complex $I$ is hampered by metformin. J Bioenerg Biomembr 38:33-42.

Bours V, Bentires-Alj M, Hellin AC, Viatour P, Robe P, Delhalle S, Benoit V, Merville MP. 2000. Nuclear factor-kB, cancer and apoptosis. Biochem Pharmacol 60:1085-1089.

Cao C, Healey S, Amaral A, Lee-Couture A, Wan S, Kouttab N, Chu W, Wan Y. 2007. ATP sensitive potassium channel: A novel target for protection against UV-induced human skin cell damage. J Cell Physiol 212:252-263.

Carlisi D, Vassallo B, Lauricella M, Emanuele S, D’Anneo A, Di Leonardo E, Di Fazio P, Vento $R$, Tesoriere G. 2008. Histone deacetylase inhibitors induce in human hepatoma HepG2 cells acetylation of p53 and histones in correlation with apoptotic effects. Int J Oncol 32:177-184.

Carlisi D, D'Anneo A, Angileri L, Lauricella M, Emanuele S, Santulli A, Vento R, Tesoriere G. 201 I. Parthenolide sensitizes hepatocellular carcinoma cells to TRAIL by inducing the expression of death receptors through inhibition of STAT3 activation. J Cell Physiol 226:1632-1641.

Chernyak BV, Bernardi P. 1996. The mitochondrial permeability transition pore is modulated by oxidative agents through both pyridine nucleotides and glutathione at two separate sites. Eur J Biochem 238:623-630.

Costantini P, Chernyak BV, Petronilli V, Bernardi P. 1996. Modulation of the mitochondrial permeability transition pore by pyridine nucleotides and dithiol oxidation at two separate sites. J Biol Chem 271:6746-6751.

Crompton M. 1999. The mitochondrial permeability transition pore and its role in cell death Biochem J 341:233-249.

Czyz M, Lesiak-Mieczkowska K, Koprowska K, Szulawska-MroczekA, Wozniak M. 2010. Cel context-dependent activities of parthenolide in primary and metastatic melanoma cells. Br J Pharmacol 160:1 144-1157.

Dawson VL, Dawson TM. 2004. Deadly conversation: Nuclear-mitochondrial cross-talk. J Bioenerg Biomembr 36:287-294.

Dewas C, Fay M, Gougerot-Pocidalo MA, El-Benna J. 2000. The mitogen-activated protein kinase extracellular signal-regulated kinase $1 / 2$ pathway is involved in formyl-methionylleucyl-phenylalanine-induced $\mathrm{p} 47^{\text {phox }}$ phosphorylation in human neutrophils. J Immunol 165:5238-5244.

Garcia-Rivas G De J, Carvajal K, Correa F, Zazueta C. 2006. RU360, a specific mitochondrial calcium uptake inhibitor, improves cardiac post-ischemic functional recovery in rats in vivo. Br J Parmacol 149:829-837.

Giuliano M, Lauricella M, Calvaruso G, Carabillò M, Emanuele S, Vento R, Tesoriere G. 1999. The apoptotic effects and synergistic interaction of sodium butyrate and MG I 32 in human retinoblastoma Y79 cells. Cancer Res 59:5586-5595.

Golstein P, Kroemer G. 2007. Cell death by necrosis: Towards a molecular definition. Trends Biochem Sci 32:37-43.

Guzman ML, Rossi RM, Neelakantan S, Li X, Corbett CA, Hassane DC, Becker MW, Bennett JM, Sullivan E, Lachowicz JL, Vaughan A, Sweeney CJ, Matthews W, Carroll M, Liesveld JL. Crooks PA, Jordan CT. 2007. An orally bioavailable parthenolide analog selectively eradicates acute myelogenous leukemia stem and progenitor cells. Blood I I 0:4427-4435. eradicates acute myelogenous leukemia stem and progenitor cells. Blood I 10:4427-4435.
Halestrap AP, Kerr PM, Javadov S, Woodfield KY. I 998. Elucidating the molecular mechanism of the permeability transition pore and its role in reperfusion injury of the heart. Biochim Biophys Acta 1366:79-94.

Hampton MB, Orrenius S. 1998. Redox regulation of apoptotic cell death. Biofactors 8: I-5 Hong SJ, Dawson TM, Dawson VL. 2004. Nuclear and mitochondrial conversations in cell death: PARP-I and AIF signaling. Trends Pharmacol Sci 25:259-264.

Javadov S, Karmazyn M, Escobales N. 2009. Mitochondrial permeability transition pore opening as a promising therapeutic target in cardiac diseases. J Pharmacol Exp Ther 330:670-678.

Jin Z, El-Deiry WS. 2005. Overview of cell death signaling pathways. Cancer Biol Ther 4:139163.

Keinan N, Tyomkin D, Shoshan-Barmatz V. 2010. Oligomerization of the mitochondrial protein voltage-dependent anion channel is coupled to the induction of apoptosis. Mol Cell Biol 30:5698-5709.

Kelly KJ, Sandoval RM, Dunn KW, Molitoris BA, Dagher P. 2003. A novel method to determine specificity and sensitivity of the TUNEL reaction in the quantitation of apoptosis. Am J Physiol Cell Physiol 284:1309-1318.

Kim JH, Liu L, Lee SO, Kim YT, You KR, Kim DG. 2005. Susceptibility of cholangiocarcinoma cells to parthenolide-induced apoptosis. Cancer Res 65:6312-6320.

Kurdi M, Booz GW. 2007. Evidence that IL-6-type cytokine signalling in cardiomyocytes is inhibited by oxidative stress: Parthenolide targets JAKI activation by generating ROS.J Cell Physiol 212:424-431.

Kurdi M, Bowers MC, Dado J, Booz GW. 2007. Parthenolide induces a distinct pattern of oxidative stress in cardiac myocytes. Free Radic Biol Med 42:474-48I.

Kwok BH, Koh B, Ndubuisi MI, Elofsson M, Crews CM. 200I. The anti-inflammatory natural product parthenolide from the medicinal herb Feverfew directly binds to and inhibits $1 \kappa B$ kinase. Chem Biol 8:759-766.

Lambert IH, Klausen TK, Bergdahl A, Hougaard C, Hoffmann EK. 2009. ROS activate KCl cotrasport in nonadherent Ehrlich ascites cells but $\mathrm{K}^{+}$and $\mathrm{Cl}^{-}$channels in adherent Ehrlich Lettré and NIH3T3 cells. Am J Physiol Cell Physiol 297:CI 98-C206.

Liu JW, Cai MX, Xin Y, Wu QS, Ma J, Yang P, Xie HY, Huang DS. 20I0. Parthenolide induces proliferation inhibition and apoptosis of pancreatic cancer cells in vitro. Exp Clin Cancer Res 10:108-115.

McStay GP, Clarke SJ, Halestrap AP. 2002. Role of critical thiol groups on the matrix surface of the adenine nucleotide translocase in the mechanism of the mitochondrial permeability transition pore. Biochem J 367:54I-548

Moon EJ, Sonveaux P, Porporato PE, Danhier P, Gallez B, Batinic-Haberle I, Nien YC, Schroeder T, Dewhirst MW. 2010. NADPH oxidase-mediated reactive oxygen species production activates hypoxia-inducible factor-I (HIF-I) via the ERK pathway after hyperthermia treatment. Proc Natl Acad Sci 107:20477-20482. 
Nakshatri H, Rice SE, Bhat-Nakshatri P. 2004. Antitumor agent parthenolide reverses resistance of breast cancer cells to tumor necrosis factor-related apoptosis-inducing ligand through sustained activation of c-Jun $\mathrm{N}$-terminal kinase. Oncogene 23:7330-7344.

Norberg E, Gogvadze V, Ott M, Horn M, Uhlén P, Orrenius S, Zhivotovsky B. 2008. An increase in intracellular $\mathrm{Ca}^{2+}$ is required for the activation of mitochondrial calpain to release AIF during cell death. Cell Death Differ 15:1857-1864.

Olivier S, Robe P, Bours V. 2006. Can NF-kB be a target for novel and efficient anti-cance agents? Biochem Pharmacol 72:1054-1068

Otera H, Ohsakaya S, Nagaura Z, Ishihara N, Mihara K. 2005. Export of mitochondrial AIF in response to proapoptotic stimuli depends on processing at the intermembrane space. EMBO j 24:1375-1386.

Pardo J, Pérez-Galán P, Gamen S, Marzo I, Monleón I, Kaspar AA, Susín SA, Kroemer G, Krensky AM, Naval J, Anel A. 200I. A role of the mitochondrial apoptosis-inducing factor in granulysin-induced apoptosis. J Immunol 167:1222-1229.

Pareek A, Suthar M, Rathore GS, Bansal V. 20II. Feverfew (Tanacetum parthenium L.): A systematic review. Pharmacogn Rev 5:103-110.

Petronilli V, Costantini P, Scorrano L, Colonna R, Passamonti S, Bernardi P. 1994. The voltage sensor of the mitochondrial permeability transition pore is tuned by the oxidationreduction state of vicinal thiols. Increase of the gating potential by oxidants and its reversal by reducing agents. J Biol Chem 269:16638-16642.

Polster BM, Basañez G, Etxebarria A, Hardwick JM, Nicholls DG. 2005. Calpain I induces cleavage and release of apoptosis-inducing factor from isolated mitochondria. J Biol Chem 280:6447-6454.

Ravi R, Bedi A. 2004. NF-kappaB in cancer-A friend turned foe. Drug Resist Updat 7:53-67. Reubold TF, Eschenburg S. 2012. A molecular view on signal transduction by the apoptosome. Cell Signal 24:1420-1425.

Samali A, Nordgren H, Zhivotovsky B, Peterson E, Orrenius S. 1999. A comparative study of apoptosis and necrosis in HepG2 cells: Oxidant-induced caspase inactivation leads to necrosis. Biochem Biophys Res Commun 255:6-1I.

Satoh T, Nakatsuka D, Watanabe Y, Nagata I, Kikuchi H, Namura S. 2000. Neuroprotection by MAPK/ERK kinase inhibition with U0I 26 against oxidative stress in a mouse neuronal cell line and rat primary cultured cortical neurons. Neurosci Lett 288:163-166.

Scharstuhl A, Mutsaers HA, Pennings SW, Russel FG, Wagener FA. 2009. Involvement of VDAC, Bax and Ceramides in the efflux of AIF from mitochondria during curcumininduced apoptosis. Plos One 4:e6688.

Sevrioukova IF. 20II. Apoptosis-inducing factor: Structure, function, and redox regulation. Antioxid Redox Signal 14:2545-2579.

Shanmugam R, Kusumanchi P, Cheng L, Crooks P, Neelakantan S, Matthews W, Nakshatri H Sweeney CJ. 2010. A water-soluble parthenolide analogue suppresses in vivo prostate cancer growth by targeting NF-kB and generating reactive oxygen species. Prostate 70:1074-1086.

Shanmugam R, Kusumanchi P, Appaiah H, Cheng L, Crooks P, Neelakantan S, Peat T, KlaunigJ, Matthews W, Nakshatri H, Sweeney CJ. 20II. A water soluble parthenolide analog suppresses in vivo tumor growth of two tobacco-associated cancers, lung and bladder cancer, by targeting NF-kB and generating reactive oxygen species. Int J Cancer I28:248 I2494

Shen HM, Liu ZG. 2006. JNK signaling pathway is a key modulator in cell death mediated by reactive oxygen and nitrogen species. Free Radical Biol Med 40:928-939.

Shoshan-Barmatz V, Keinan N, Abu-Hamad S, Tyomkin D, Aram L. 2010. Apoptosis is regulated by the VDACI N-terminal region and by VDAC oligomerization: Release of cytochrome c, AIF and Smac/Diablo. Biochim Biophys Acta 1797: |29|-|29|

Song H, Cha MJ, Song BW, Kim IK, Chang W, Lim S, Choi EJ, Ham O, Lee SY, Chung N, Jang Y, Hwang KC. 20I0. Reactive oxygen species inhibit adhesion of mesenchymal stem cells implanted into ischemic myocardium via interference of focal adhesion complex. Stem Cells 28:555-563.

Steele AJ, Jones DT, Ganeshaguru K, Duke VM, Yogashangary BC, North JM, Lowdell MW, Kottaridis PD, Mehta AB, Prentice AG, Hoffbrand AV, Wickremasinghe RG. 2006. The sesquiterpene lactone parthenolide induces selective apoptosis of B-chronic lymphocytic leukemia cells in vitro. Leukemia 20:1073-1079.

Sumner H, Salan U, Knight DW, Hoult JR. 1992. Inhibition of 5-lipoxygenase and cyclooxygenase in leukocytes by feverfew. Involvement of sesquiterpene lactones and other components. Biochem Pharmacol 43.2313-2320.

Sun Y, St Clair DK, Xu Y, Crooks PA, St Clair WH. 2010. A NADPH oxidase-dependent redox signaling pathway mediates the selective radiosensitization effect of parthenolide in prostate cancer cells. Cancer Res 70:2880-2890.

Susin SA, Daugas E, Ravagnan L, Samejima K, Zamzami N, Loeffler M, Costantini P, Ferri KF Irinopoulou T, Prévost MC, Brothers G, Mak TW, Penninger J, Earnshaw WC, Kroemer G. 2000. Two distinct pathways leading to nuclear apoptosis. J Exp Med 192:57I-580.

Tait SW, Green DR. 2008. Caspase-independent cell death: Leaving the set without the final cut. Oncogene 27:6452-6461.

Wang $\mathrm{H}$, Joseph JA. 1999. Quantifying cellular oxidative stress by dichlorofluorescein assay using microplate reader. Free Radic Biol Med 27:612-616

Wang W, Adachi M, Kawamura R, Sakamoto H, Hayashi T, Ishida T, Imai K, Shinomura $Y$. 2006. Parthenolide-induced apoptosis in multiple myeloma cells involves reactive oxygen species generation and cell sensitivity depends on catalase activity. Apoptosis II:2225-2235

Wen J, You KR, Lee SY, Song CH, Kim DG. 2002. Oxidative stress-mediated apoptosis. The anticancer effect of the sesquiterpene lactone parthenolide. J Biol Chem 277:3895438964

Wu F, Tyml K, Wilson JX. 2008. iNOS expression requires NADPH oxidase-dependent redox signaling in microvascular endothelial cells. J Cell Physiol II7:207-214

Zhang S, Ong CN, Shen HM. 2004. Critical roles of intracellular thiols and calcium in parthenolide-induced apoptosis in human colorectal cancer cells. Cancer Lett 208: 143-153.

Zunino SJ, Ducore JM, Storms DH. 2007. Parthenolide induces significant apoptosis and production of reactive oxygen species in high-risk pre-B leukemia cells. Cancer Lett 254:119-127. 